Prepared in cooperation with the St. Johns River Water Management District

\title{
Relations between Groundwater Levels and Anthropogenic and Meteorological Stressors at Selected Sites in East-Central Florida, 1995-2007
}
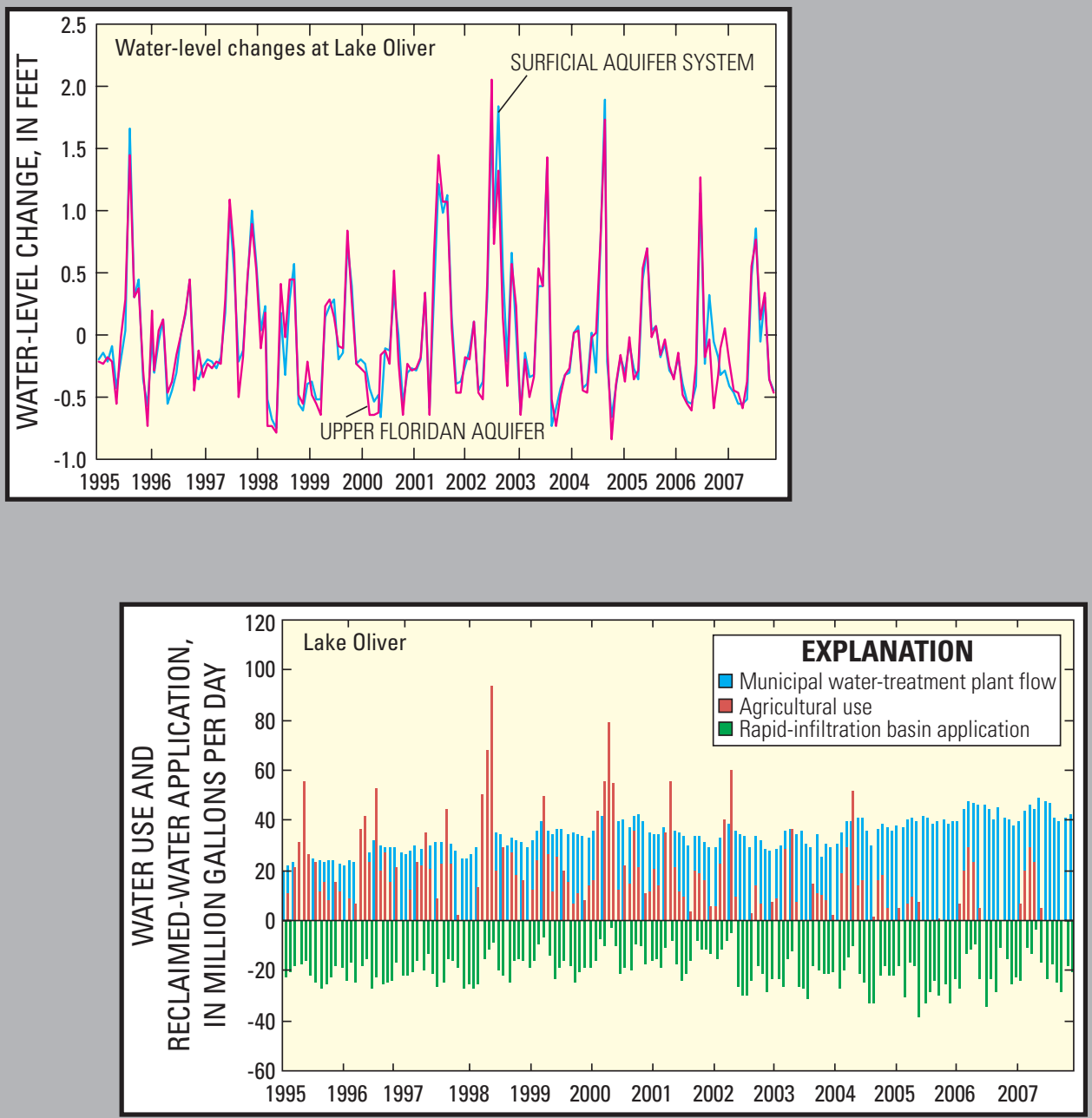

Scientific Investigations Report 2010-5046

U.S. Department of the Interior

U.S. Geological Survey 



\section{Relations between Groundwater Levels and Anthropogenic and Meteorological Stressors at Selected Sites in East-Central Florida, 1995-2007}

By Louis C. Murray, Jr.

Prepared in cooperation with the St. Johns River Water Management District

Scientific Investigations Report 2010-5046 


\title{
U.S. Department of the Interior \\ KEN SALAZAR, Secretary \\ U.S. Geological Survey \\ Marcia K. McNutt, Director
}

\section{U.S. Geological Survey, Reston, Virginia: 2010}

\author{
For more information on the USGS — the Federal source for science about the Earth, its natural and living resources, \\ natural hazards, and the environment, visit http://www.usgs.gov or call 1-888-ASK-USGS \\ For an overview of USGS information products, including maps, imagery, and publications, \\ visit http://www.usgs.gov/pubprod \\ To order this and other USGS information products, visit http://store.usgs.gov
}

\begin{abstract}
Any use of trade, product, or firm names is for descriptive purposes only and does not imply endorsement by the U.S. Government.

Although this report is in the public domain, permission must be secured from the individual copyright owners to reproduce any copyrighted materials contained within this report.
\end{abstract}

Suggested citation:

Murray, L.C. Jr., 2010, Relations between Groundwater Levels and Anthropogenic and Meteorological Stressors at Selected Sites in East-Central Florida, 1995-2007: U.S. Geological Survey Scientific Investigations Report 2010-5046, 31 p. 


\section{Acknowledgments}

Several people provided valuable water-use and related information required for this study. They include JoAnne Bowden and Marcella DeMoss (Florida Department of Environmental Protection); Steve Brown, Patrick Burger, Bruce Florence, and George Robinson (St. Johns River Water Management District); Randy Corbin (Southlake Utilities); Phillip Cross (Water Conserv II); Scott Fick and Amber Morgan (Tohopekaliga Water Authority); Scotty Haws (Utilities, Inc.); Ted McKim (Reedy Creek Improvement District); and Cecile Stewart (Polk County Utilities). 



\section{Contents}

Abstract
Introduction
Purpose and Scope
Methods of Investigation
Data Collection and Analyses
$\quad$ Statistical Methods
Relation Between Groundwater Levels and Anthropogenic and Meteorological Stressors
$\quad$ Simple Linear Regression
Multivariate Analyses
$\quad$ Svaluation of Regional Pumpage Effects

\section{Figures}

1. Locations of selected monitoring well sites and nearby National Oceanic and Atmospheric Administration rainfall stations in east-central Florida.......................................

2. Geologic and hydrogeologic units in east-central Florida ................................................

3. Graphs showing water levels and changes in water levels at the Charlotte Street and Lake Oliver monitoring well sites, 1995-2007.....

4. Maps showing locations of municipal water-treatment plants, permitted agricultural crop acreages, and rapid-infiltration basins located within 10 miles of the Charlotte Street and Lake Oliver monitoring well sites, 1995-2007

5-10. Graphs showing:

5. Water use near the Charlotte Street and Lake Oliver monitoring well sites, 1995-2007

6. Precipitation, potential evapotranspiration, and difference between precipitation and potential evapotranspiration at the Sanford and Clermont National Oceanic and Atmospheric Administration rainfall stations, 1995-2007.

7. Mean monthly water levels in the surficial aquifer system and Upper Floridan aquifer at the Charlotte Street and Lake Oliver monitoring well sites and the 9-month moving average of precipitation ( $\left.\mathrm{PREC}_{9 \mathrm{AA}}\right)$ at the Sanford and Clermont National Oceanic and Atmospheric Administration rainfall stations, 1995-2007 
8. Mean monthly change in surficial aquifer system and Upper Floridan aquifer water levels at the Charlotte Street monitoring well site and the 2-month moving average of change in nearby water-treatment plant flow $\left(\Delta \mathrm{WTP}_{2 \mathrm{MA}}\right)$, and mean monthly change in surficial aquifer and Upper Floridan aquifer water levels at the Lake Oliver monitoring well site and the 2-month moving average of the difference between monthly precipitation and potential evapotranspiration (P-PET) ${ }_{2 \mathrm{MA}}$ at the Clermont NOAA rainfall station, 1995-2007 ......12

9. Standardized partial residuals of mean monthly changes in Upper Floridan aquifer and surficial aquifer system water levels and explanatory variables in best regressed equations, 1995-2007

10. Cumulative departure from long-term (1931-2007) average rainfall at the Sanford and Clermont NOAA rainfall stations

\section{Tables}

1. Results of simple linear regression of groundwater levels and changes in groundwater levels measured at the Charlotte Street and Lake Oliver monitoring well sites with selected anthropogenic and meteorological stressors, 1995-2007

2. Results of multivariate regression of groundwater levels and changes in groundwater levels at Charlotte Street with anthropogenic and meteorological stressors, 1995-2007

3. Results of multivariate regression of groundwater levels and changes in groundwater levels at Lake Oliver with anthropogenic and meteorological stressors, 1995-2007

4. Results of multivariate regression of seasonal changes in groundwater levels at Charlotte Street with anthropogenic and meteorological stressors, 1995-2007

5. Results of multivariate regression of seasonal changes in groundwater levels at Lake Oliver with anthropogenic and meteorological stressors, 1995-2007.

6. Results of multivariate regression of changes in groundwater levels at Charlotte Street with anthropogenic and meteorological stressors during prolonged wet and dry periods between 1995 and 2007

7. Results of multivariate regression of changes in groundwater levels at Lake Oliver with anthropogenic and meteorological stressors during prolonged wet and dry periods between 1995 and 2007

8. Results of multivariate regression of changes in groundwater levels at Charlotte Street with anthropogenic and meteorological stressors, 1995-2007, as affected by radially dependent variations in anthropogenic stressors.

9. Results of multivariate regression of changes in groundwater levels at Lake Oliver with anthropogenic and meteorological stressors, 1995-2007, as affected by radially dependent variations in anthropogenic stressors.

1-1. Water treatment plants located within 10 miles of the Charlotte Street monitoring well site

1-2. Water-treatment plants and rapid-infiltration basins located within 10 miles of the Lake Oliver monitoring well site 


\section{Conversion Factors, Abbreviations, Acronyms, and Datum}

\begin{tabular}{rcll}
\multicolumn{1}{r}{ Multiply } & By & \multicolumn{1}{c}{ To obtain } \\
\hline inch (in.) & 25.4 & millimeter $(\mathrm{mm})$ \\
inch per year & 25.4 & millimeter per year $(\mathrm{mm} / \mathrm{yr})$ \\
foot $(\mathrm{ft})$ & 0.3048 & meter $(\mathrm{m})$ \\
mile (mi) & 1.609 & kilometer $(\mathrm{km})$ \\
acre & 4,047 & square meter $\left(\mathrm{m}^{2}\right)$ \\
million gallons per day (Mgal $/ \mathrm{d})$ & 0.04381 & cubic meters per second $\left(\mathrm{m}^{3} / \mathrm{s}\right)$ \\
\hline
\end{tabular}

\begin{tabular}{|r|l|} 
ANN & Artificial neural networks \\
AFSIRS & Agricultural Field Scale Irrigation Requirements Simulation \\
FAS & Floridan aquifer system \\
FDEP & Florida Department of Environmental Protection \\
GIS & Geographic Information System \\
ICU & Intermediate confining unit \\
LFA & Lower Floridan aquifer \\
MSCU & Middle semiconfining unit \\
NOAA & National Oceanic and Atmospheric Administration \\
OCPU & Orange County Public Utilities \\
OUC & Orlando Utilities Commission \\
P (or prec) & Precipitation \\
PET & Potential evapotranspiration \\
RCID & Reedy Creek Improvement District \\
RIB & Rapid infiltration basin \\
R $^{2}$ & Coefficient of determination \\
SAS & Surficial aquifer system \\
SFWMD & South Florida Water Management District \\
SJRWMD & St. John's River Water Management District \\
SWFWMD & Southwest Florida Water Management District \\
UFA & Upper Floridan aquifer \\
USGS & U.S. Geological Survey \\
VIF & Variance inflation factor \\
WTP & Water-treatment plant \\
\hline
\end{tabular}

Vertical coordinate information is referenced to the National Geodetic Vertical Datum of 1929 (NGVD 29) 



\title{
Relations between Groundwater Levels and Anthropogenic and Meteorological Stressors at Selected Sites in East-Central Florida, 1995-2007
}

\author{
By Louis C. Murray, Jr.
}

\section{Abstract}

Multivariate linear regression analyses were used to define the relations of water levels in the Upper Floridan aquifer (UFA) and surficial aquifer system (SAS) to anthropogenic and meteorological stressors between 1995 and 2007 at two monitoring well sites (Charlotte Street and Lake Oliver) in east-central Florida. Anthropogenic stressors of interest included municipal and agricultural groundwater withdrawals, and application of reclaimed-water to rapid-infiltration basins (source of aquifer recharge). Meteorological stressors included precipitation and potential evapotranspiration. Overall, anthropogenic and meteorological stressors accounted for about 40 to 89 percent of the variance in UFA and SAS groundwater levels and water-level changes. While mean monthly water levels were better correlated with monthly stressor values, changes in UFA and SAS water levels were better correlated with changes in stressor values. Water levels and water-level changes were influenced by system persistence as the movingaveraged values of both stressor types, which accounted for the influence of the previous month(s) conditions, consistently yielded higher adjusted coefficients of determination $\left(\mathrm{R}_{\text {adj }}^{2}\right)$ values than did single monthly values.

While monthly water-level changes tend to be influenced equally with both stressors across the hydrologically averaged 13-year period, changes were more influenced by one stressor or the other seasonally and during extended wet and dry periods. Seasonally, UFA water-level changes tended to be more influenced by anthropogenic stressors than by meteorological stressors, while changes in SAS water levels tended to be more influenced by meteorological stressors. During extended dry periods (12 months or greater), changes in UFA water levels at Charlotte Street were more affected by anthropogenic stressors than by meteorological stressors, while changes in SAS levels were more affected by meteorological stressors. At Lake Oliver, changes in both UFA and SAS water levels were better correlated with meteorological stressors for all but the wet period between April 1995 and April 1996. Interestingly, changes in both UFA and SAS water levels at Charlotte Street were also better correlated with anthropogenic stressors during a similar wet period between April 1995 and June 1996 when substantive reductions in groundwater withdrawals resulted in appreciable recovery of both UFA and SAS water levels.

The regional effects of anthropogenic stressors had limited influence on water-level changes at Charlotte Street and virtually no influence on changes at Lake Oliver. When regressed against the $2.2 \mathrm{Mgal} / \mathrm{d}$ (million gallons per day) of municipal withdrawals located within 2 miles of the Charlotte Street site, water-level changes were influenced solely by precipitation and potential evapotranspiration. At a radius of 2.5 miles, however, where cumulative withdrawals totaled about $9.5 \mathrm{Mgal} / \mathrm{d}$, water-level changes were equally influenced by both anthropogenic and meteorological stressors. Withdrawals located at distances of greater than 3 miles from this site had no appreciable effect on relations between waterlevel changes and these stressors. At Lake Oliver, changes in UFA water levels were equally influenced by both stressors regardless of distance, while changes in SAS levels were more influenced by meteorological stressors at all distances.

\section{Introduction}

Groundwater withdrawals have increased steadily during the latter half of the 20th century in east-central Florida. In Orange County alone, withdrawals have more than doubled to about $280 \mathrm{Mgal} / \mathrm{d}$ between 1975 and 2000 (Marella, 2004). Most potable water used for municipal, agricultural, commercial, and industrial supply is pumped from the Floridan aquifer system - a semiconfined sequence of highly transmissive carbonate rocks. Withdrawals from this system not only lower the potentiometric surface, which can adversely affect the discharge from Upper Floridan aquifer (UFA) springs, but also can lower water levels in the overlying unconfined surficial aquifer system (SAS). Lower SAS water levels, in turn, can affect other sensitive water resources such as wetlands and associated ecosystems. In addition to groundwater withdrawals, natural meteorologic stressors, such as precipitation and evapotranspiration, influence groundwater levels and affect water resources; 
however, it is often not apparent how these factors contribute to changes in SAS and UFA water levels. Consequently, trends and fluctuations observed in hydrologic data reflect the combined effects of both meteorologic and anthropogenic influences, and thus, pose difficulties for water managers tasked with assessing the impacts of new water-use permits (i.e., groundwater pumpage) in resource-sensitive areas, or of implementing water-use restrictions during periods of drought.

The U.S. Geological Survey (USGS), in cooperation with the St. Johns River Water Management District (SJRWMD) and the Southwest Florida Water Management District (SWFWMD), began a 3-year study in 2008 to quantify relations between groundwater levels, lake levels, and springflow with anthropogenic and meteorological stressors in eastcentral Florida. While artificial neural networks (ANN) and regional groundwater flow modeling are the selected tools being used in the regional analyses, this study applies multivariate linear regression as an additional means for analyzing relations between groundwater levels, withdrawals, and selected meteorological parameters on a more localized sitespecific basis. The approach used here accounts for the effects of anthropogenic stressors such as agricultural withdrawals and artificial recharge of groundwater not being explicitly considered in the regional ANN analyses. Also, this study examines the effects of seasonal variations in stressor conditions on water levels, as well as the influence of extended wet and dry periods, whereas the regional studies are focused on a composited and hydrologically averaged period of record. Accordingly, results from these analyses should provide useful insight for interpreting the results from ANN and the groundwater modeling studies.

\section{Purpose and Scope}

This report describes relations between groundwater levels measured at two monitoring well sites in east-central Florida and anthropogenic and meteorological stressors using multivariate linear regression. Both SAS and UFA water levels, and water-levels changes, are included as response variables. The selected sites, "Charlotte" Street in western Seminole County and "Lake Oliver" in southwestern Orange County, are located within the Central Florida Coordination Area, a multi-county area that has been identified by the SJRWMD, SWFWMD, and South Florida Water Management District (SFWMD) as having sensitive water-resource issues that restrict future groundwater development (fig. 1). Each site consists of two wells, one in the SAS and one in the UFA, each equipped with continuous recording pressure transducers.

Anthropogenic stressors of interest include groundwater withdrawal from the UFA required to meet municipal and agricultural demands, and reclaimed-water application to rapid-infiltration basins (RIBs), which provides recharge to the system. Meteorological stressors of interest include precipitation and potential evapotranspiration (PET). PET can be defined as the measure of the ability of the atmosphere to remove water from the surface through the processes of evaporation and transpiration assuming no limit on water supply. Meteorological data used in this study were collected at the nearby Sanford and Clermont National Oceanic and Atmospheric Administration (NOAA) rainfall stations (fig. 1).

Analyses were conducted over a 13-year period of record (1995-2007) to be consistent with the timeframe being used in the regional and concurrent data-mining and numerical modeling studies. This period of record largely is based on the availability of suitable water-use information and, although a longer period would have been preferable, the period does contain both wet and dry hydrologic extremes and is considered representative of average meteorological conditions. The relations described in this report between groundwater levels and anthropogenic and meteorological stressors provide examples of how the multivariate regression tool can be used to better understand the relative sensitivity of groundwater levels, and water-level changes, to these stressors.

\section{Site Descriptions}

The Charlotte Street and Lake Oliver sites are situated in different land-use and hydrogeologic settings. Charlotte Street is located in a wetland environment surrounded by a highly urbanized area of both residential and commercial water users. Lake Oliver is located in a less developed urban setting but one with greater agricultural water usage, primarily for citrus crops. The Lake Oliver site also is situated within a few miles of several water-reuse facilities that discharge reclaimed water to RIBs constructed in karstic areas having relatively deep water tables. Given that most of these RIBs are located within internally drained basins, previous groundwater flow modeling studies have assumed that most or all of the applied water eventually recharges the UFA (Murray and Halford, 1996; Knowles and others, 2002). As a result, water applied to RIBs has the potential to increase, or to mute pumpage-induced decreases in, UFA and SAS water levels at Lake Oliver and was therefore included as an anthropogenic stressor in this study.

The principal geologic and hydrogeologic units in east-central Florida are shown in figure 2. The SAS is the uppermost water-bearing unit and consists of an unconfined sequence of Holocene to early Pliocene quartz sands with varying proportions of silt and clay. The system is recharged at both study sites by rainfall and is discharged by downward leakage to the UFA and by evapotranspiration.

The SAS is underlain by the intermediate confining unit (ICU), a sequence of Pliocene to Miocene sands, silts, and clays that retard the vertical movement of water between the SAS and UFA. Thickness of the ICU at Charlotte Street $(82 \mathrm{ft})$ is about twice that at Lake Oliver (42 ft) (Murray, 2007). Leakance of the ICU, which is equal to the equivalent vertical hydraulic conductivity of the unit divided by its thickness, influences the head differential between the SAS and UFA and controls the rate of groundwater movement between 


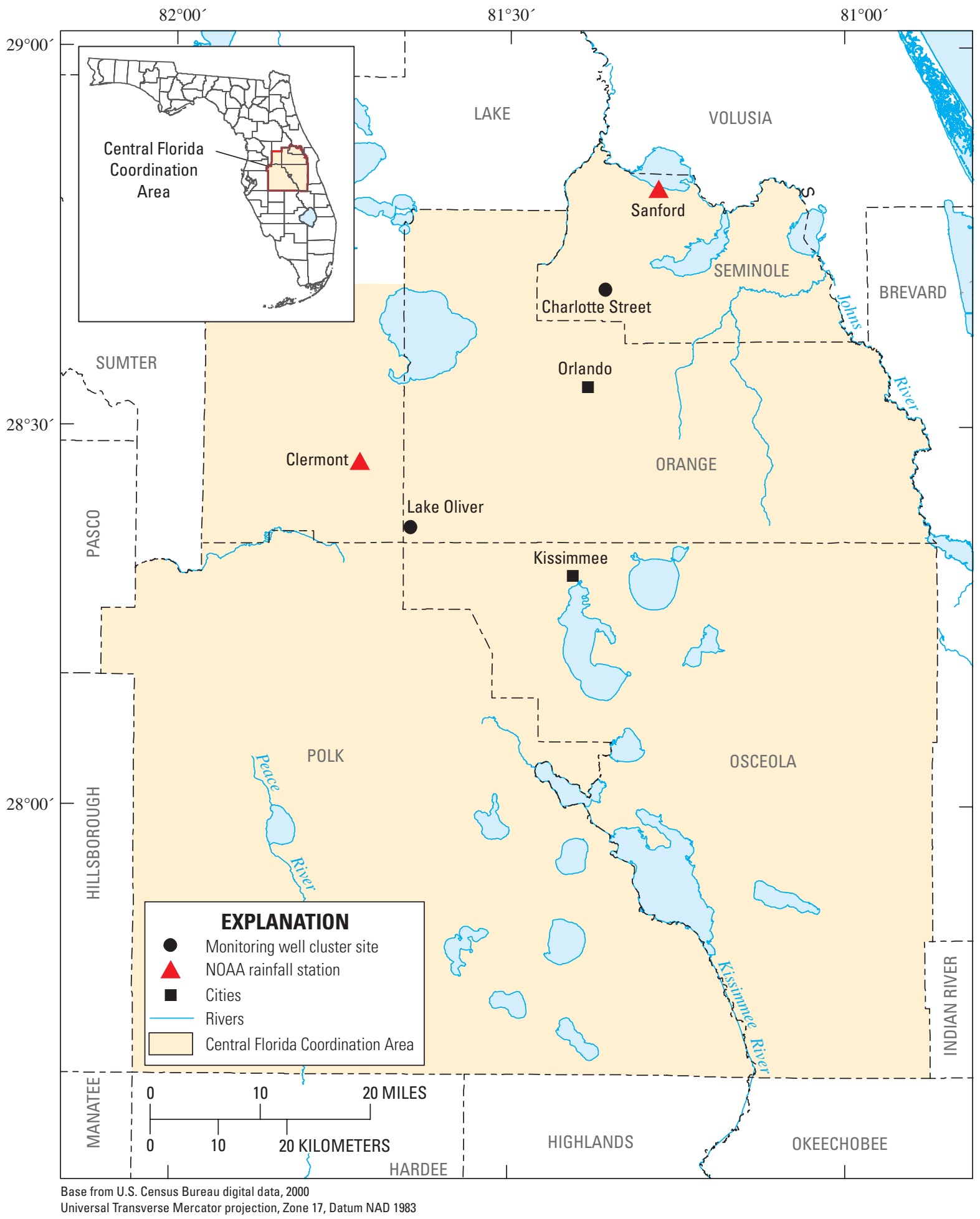

Figure 1. Locations of selected monitoring well sites and nearby National Oceanic and Atmospheric Administration (NOAA) rainfall stations in east-central Florida. 


\begin{tabular}{|c|c|c|c|c|c|c|}
\hline \multicolumn{2}{|c|}{ SERIES } & $\begin{array}{l}\text { STRATIGRAPHIC } \\
\text { UNIT }\end{array}$ & \multicolumn{2}{|l|}{ LITHOLOGY } & $\begin{array}{l}\text { HYDROGEOLOGIC } \\
\text { UNIT }\end{array}$ & $\begin{array}{c}\text { APPROXIMATE } \\
\text { THICKNESS } \\
\text { (feet) }\end{array}$ \\
\hline \multicolumn{2}{|c|}{ HOLOCENE } & \multirow{4}{*}{$\begin{array}{l}\text { UNDIFFERENTIATED } \\
\text { DEPOSITS }\end{array}$} & \multicolumn{2}{|l|}{$\begin{array}{l}\text { Alluvium, freshwater marl, peats, and muds } \\
\text { in stream and lake bottoms. Also, some } \\
\text { dunes and other windblown sand }\end{array}$} & \multirow{3}{*}{$\begin{array}{l}\text { SURFICIAL } \\
\text { AQUIFER } \\
\text { SYSTEM }\end{array}$} & \multirow{3}{*}{$0-150$} \\
\hline \multirow{2}{*}{\multicolumn{2}{|c|}{ PLEISTOCENE }} & & \multirow{2}{*}{\multicolumn{2}{|c|}{$\begin{array}{l}\text { Mostly quartz sand. Locally may contain } \\
\text { deposits of shell and thin beds of clay }\end{array}$}} & & \\
\hline & & & & & & \\
\hline \multicolumn{2}{|c|}{ PLIOCENE } & & \multicolumn{2}{|l|}{$\begin{array}{l}\text { Interbedded deposits of sand, shell } \\
\text { fragments, and sandy clay; base may } \\
\text { contain phosphatic clay }\end{array}$} & \multirow{2}{*}{$\begin{array}{l}\text { INTERMEDIATE } \\
\text { CONFINING } \\
\text { UNIT }\end{array}$} & \multirow{2}{*}{$0-500$} \\
\hline \multicolumn{2}{|c|}{ MIOCENE } & $\begin{array}{l}\text { HAWTHORN } \\
\text { GROUP }\end{array}$ & \multicolumn{2}{|l|}{$\begin{array}{l}\text { Interbedded quartz, sand, silt and clay, } \\
\text { often phosphatic; phosphatic limestone } \\
\text { often found at base of formation }\end{array}$} & & \\
\hline \multirow{3}{*}{$\begin{array}{l}\text { 岁 } \\
\text { 엄 }\end{array}$} & UPPER & $\begin{array}{l}\text { OCALA } \\
\text { LIMESTONE }\end{array}$ & $\begin{array}{l}\text { Cream to tan, soft to hard, granular, } \\
\text { porous, foraminiferal limestone }\end{array}$ & \multirow{4}{*}{ 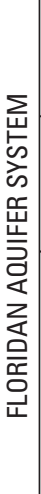 } & $\begin{array}{l}\text { UPPER } \\
\text { FLORIDAN } \\
\text { AQUIFER }\end{array}$ & $100-400$ \\
\hline & MIDDLE & $\begin{array}{l}\text { AVON PARK } \\
\text { FORMATION }\end{array}$ & $\begin{array}{l}\text { Light brown to brown, soft to hard, } \\
\text { porous to dense, granular to chalky, } \\
\text { fossiliferous limestone and brown, } \\
\text { crystalline dolomite }\end{array}$ & & $\begin{array}{l}\text { MIDDLE } \\
\text { SEMICONFINING } \\
\text { UNIT }\end{array}$ & $100-1,000$ \\
\hline & LOWER & $\begin{array}{l}\text { OLDSMAR } \\
\text { FORMATION }\end{array}$ & $\begin{array}{l}\text { Alternating beds of light brown to } \\
\text { white, chalky, porous, fossiliferous } \\
\text { limestone and porous crystalline } \\
\text { dolomite }\end{array}$ & & LOWER & $700-1500$ \\
\hline \multicolumn{2}{|c|}{ PALEOCENE } & $\begin{array}{l}\text { CEDAR KEYS } \\
\text { FORMATION }\end{array}$ & $\begin{array}{l}\text { Dolomite, with considerable anhydrite } \\
\text { and gypsum, some limestone }\end{array}$ & & AQUIFER & $100-1,000$ \\
\hline
\end{tabular}

Figure 2. Geologic and hydrogeologic units in east-central Florida (modified from Murray and Halford, 1996).

the two aquifer systems. Based on a regional groundwater flow modeling study, leakance of the ICU at the Charlotte Street and Lake Oliver sites was estimated at 0.0001 and 0.0008 day $^{-1}$, respectively (Sepulveda, 2002).

The ICU is underlain by the Floridan aquifer system (FAS), a sequence of highly-transmissive Eocene limestone and dolomitic limestone. The FAS consists of two major permeable zones, the UFA and the Lower Floridan aquifer (LFA), separated by a less permeable zone referred to as the middle semiconfining unit (MSCU). The UFA provides most of the water required to meet municipal, agricultural, and industrial/ commercial demands in east-central Florida and, along with the SAS, is the focus of this study.

Given the difference in ICU leakance values and the karst surrounding Lake Oliver, it is not surprising that the differences between SAS and UFA water levels at Lake Oliver (about 2 to $3 \mathrm{ft}$ ) are considerably less than those at Charlotte Street (about $40 \mathrm{ft}$ ), and that the fluctuations in one aquifer tend to follow those in the other aquifer more closely (fig. 3). Because the two aquifer systems at Lake Oliver are more effectively connected hydraulically than those at Charlotte Street, stresses induced in one of the aquifers at Lake Oliver-whether from withdrawals from the UFA or from precipitation to the SAS - are more likely to affect water levels in the other aquifer.

The climate at both sites is classified as humid semitropical (Tibbals, 1990). Long-term precipitation (1931-2007) averages about 53 and $52 \mathrm{in} / \mathrm{yr}$ at the Sanford and Clermont NOAA stations, respectively, with about 50 to 55 percent of these amounts occurring between June and September (Tibbals, 1990). Rates of PET also are greatest during the summer months. As a result, the arithmetic difference between monthly precipitation and PET can become negative in drierthan-normal summer months, stressing water-starved lawns and shrubbery. Groundwater withdrawals during such periods can be particularly high to meet increased irrigation demands. 

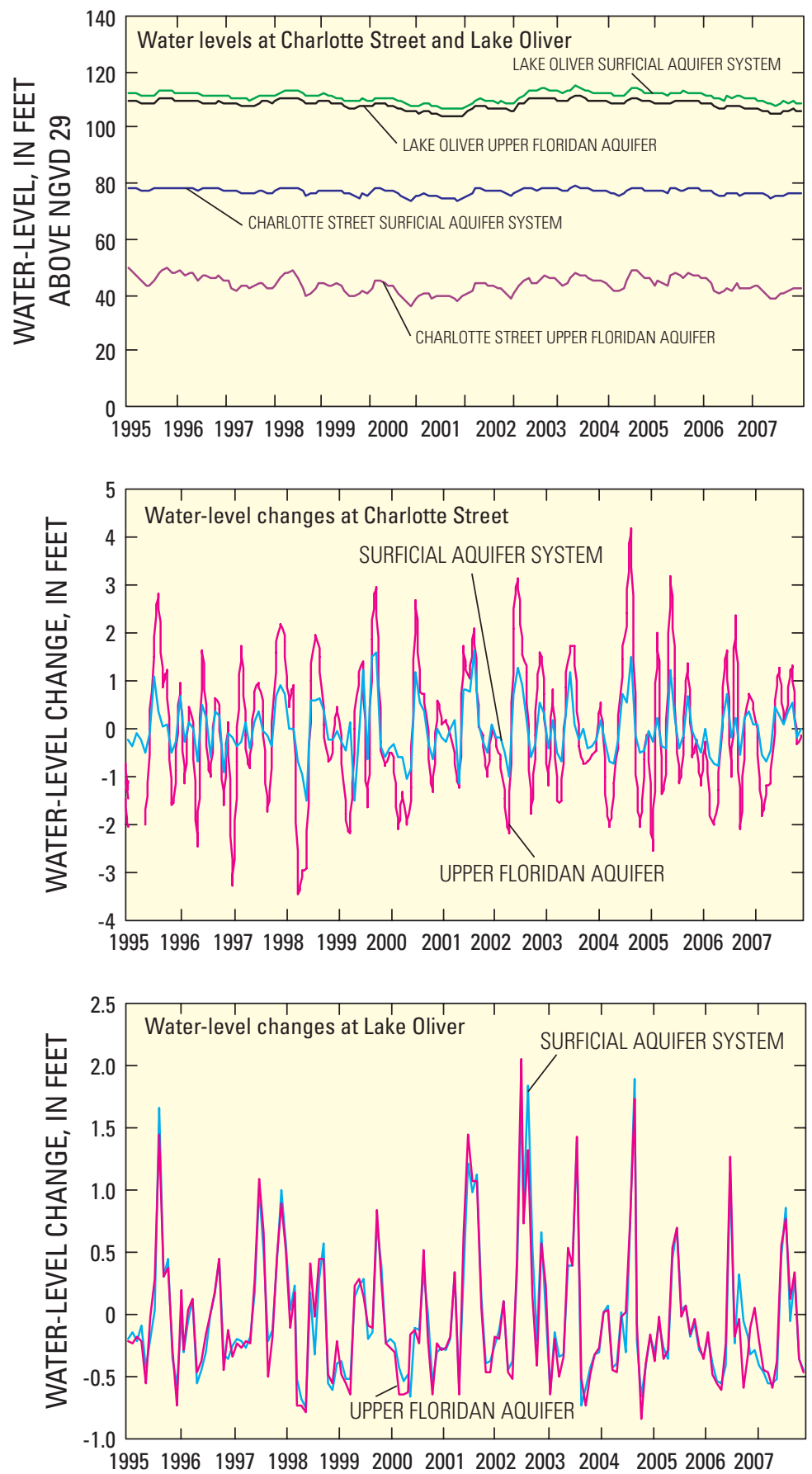

Figure 3. Water levels and changes in water levels at the Charlotte Street and Lake Oliver monitoring well sites, 1995-2007. 


\section{Methods of Investigation}

This section describes the data-collection methods and statistical techniques applied in the study. Analyses were performed on a monthly basis to be consistent with concurrent ANN and numerical modeling studies, and to account for seasonal fluctuations in water levels and changes in water levels.

\section{Data Collection and Analyses}

Data collected for this study include: (1) mean daily UFA and SAS water levels at the Charlotte Street and Lake Oliver monitoring well sites between 1995 and 2007 (mean daily values were used to calculate mean monthly water levels); (2) mean monthly flows from municipal water-treatment plants (WTPs) located within $10 \mathrm{mi}$ of each site; (3) estimated rates of agricultural water use for crops permitted within $10 \mathrm{mi}$ of the Lake Oliver site; (4) mean monthly reclaimed-water application rates to RIBs located within $10 \mathrm{mi}$ of the Lake Oliver site; and (5) precipitation and PET at the Sanford and Clermont NOAA rainfall stations. By including anthropogenic stressors located within a 10-mi radius of the study sites, the results account for, at least to some degree, the more regional effects of these stressors on groundwater levels and not just those of the single and nearest point of withdrawal or RIB loading. The locations of WTPs, RIBs, and the centroids of permitted crop acreages are shown in figure 4. Individual WTPs and RIBs are identified in appendix 1.

The monitored flows from municipal WTPs are considered reasonable approximations of the amounts of groundwater withdrawn from nearby well fields and were used here as surrogate quantities for well-specific withdrawal rates. WTP data are more readily available, and the differences between these flows and well-field withdrawal rates typically are minimal for municipal systems in east-central Florida (Murray, 2009). Also, the WTPs are located relatively close to contributing well fields and thus provide reasonable approximations of the locations of the pumpage stressor. Monthly flow rates were acquired from Florida Department of Environmental Protection (FDEP), SJRWMD, and USGS data bases. Because this study focuses on water levels in the UFA, only those plants treating raw groundwater discharged from UFA well fields were included. Several other plants operated by Orlando Utilities Commission (OUC) and Orange County Public Utilities (OCPU), although located within $10 \mathrm{mi}$ of the Charlotte Street monitoring site, were not included because respective well fields tap the LFA as the source.

Groundwater used for agricultural purposes in east-central Florida is almost exclusively withdrawn from the UFA. However, metered data needed to accurately quantify monthly withdrawal rates are largely unavailable. Alternatively, the amounts of groundwater required to irrigate the nearly 200 crop sites located near Lake Oliver were estimated by SJRWMD with the Agricultural Field Scale Irrigation Requirements Simulation (AFSIRS) model (Smajstrla, 2008). The
AFSIRS model is based on a water budget of the crop root zone and the concept that crop evapotranspiration can be estimated from PET and crop-specific water-use coefficients. The model calculates the theoretical amount of water, exclusive of precipitation, needed to meet a crop's evapotranspiration requirements without significant reduction in yield. AFSIRSbased estimates made for the approximately 2,500 acres of citrus located within the Conserv II area were not applied in this study, as reclaimed water was being used for these purposes. The locations of Conserv II citrus are closely approximated by the locations of the Conserv II rapid-infiltration basins shown in figure 4. Geographic Information System (GIS) software was used to identify the centroids of permitted acreages assumed to coincide with the locations of groundwater withdrawals.

The locations of RIB sites and reclaimed-water application rates were acquired from SJRWMD, FDEP, OCPU, Reedy Creek Improvement District (RCID), Southlake Utilities, and Utilities Incorporated. The Conserv II facility operated by OCPU and the City of Orlando, and the RCID facility, are by far the largest such facilities in the area, while the Lake Groves and Southlake facilities dispose of substantially smaller amounts of reclaimed water to RIBs.

Municipal and agricultural withdrawal rates, together with RIB application rates, are plotted in figure 5. All usages depict seasonal fluctuations. Highest withdrawals typically occur in the spring months while lowest withdrawals occur in the winter months. WTP flows near Charlotte Street averaged about $58 \mathrm{Mgal} / \mathrm{d}$ between 1995 and 2007 as compared with $35 \mathrm{Mgal} / \mathrm{d}$ for Lake Oliver. At Lake Oliver, AFSIRS-based estimates of agricultural withdrawals averaged about $17 \mathrm{Mgal} / \mathrm{d}$ and varied dramatically from one month to the next but tended to be greatest during the spring growing season and least in the winter. Overall, agricultural water use in Orange County has declined in the past 20 to 30 years as citrus groves have been replaced by more urbanized residential usages. RIB application rates near Lake Oliver averaged about $20 \mathrm{Mgal} / \mathrm{d}$ between 1995 and 2007 and were usually greatest in wetter periods when irrigation demands were low, and lowest in drier periods when irrigation demands were high. RIB application rates are depicted as negative values in figure 5 because these applications would tend to increase groundwater levels, while municipal and agricultural withdrawals would lower groundwater levels.

Monthly PET values were estimated by the PriestleyTaylor method (Priestley and Taylor, 1972). Data required for the model were obtained from land- and satellite-based measurements of net radiation and air temperature made within a 2-km (1.24 mi) distance of the Sanford and Clermont NOAA stations. These measurements are recorded in support of an ongoing statewide study of PET (U.S. Geological Survey, 2009). As seen in figure 6, PET depicts a clear seasonal pattern with rates greatest between June and September, and least between December and March. Greatest negative differences between precipitation and PET, a gross measure of the amount of "available water," typically occur in drier-than-normal summer months, while greatest positive differences occur in wetter-than-normal winter months. 

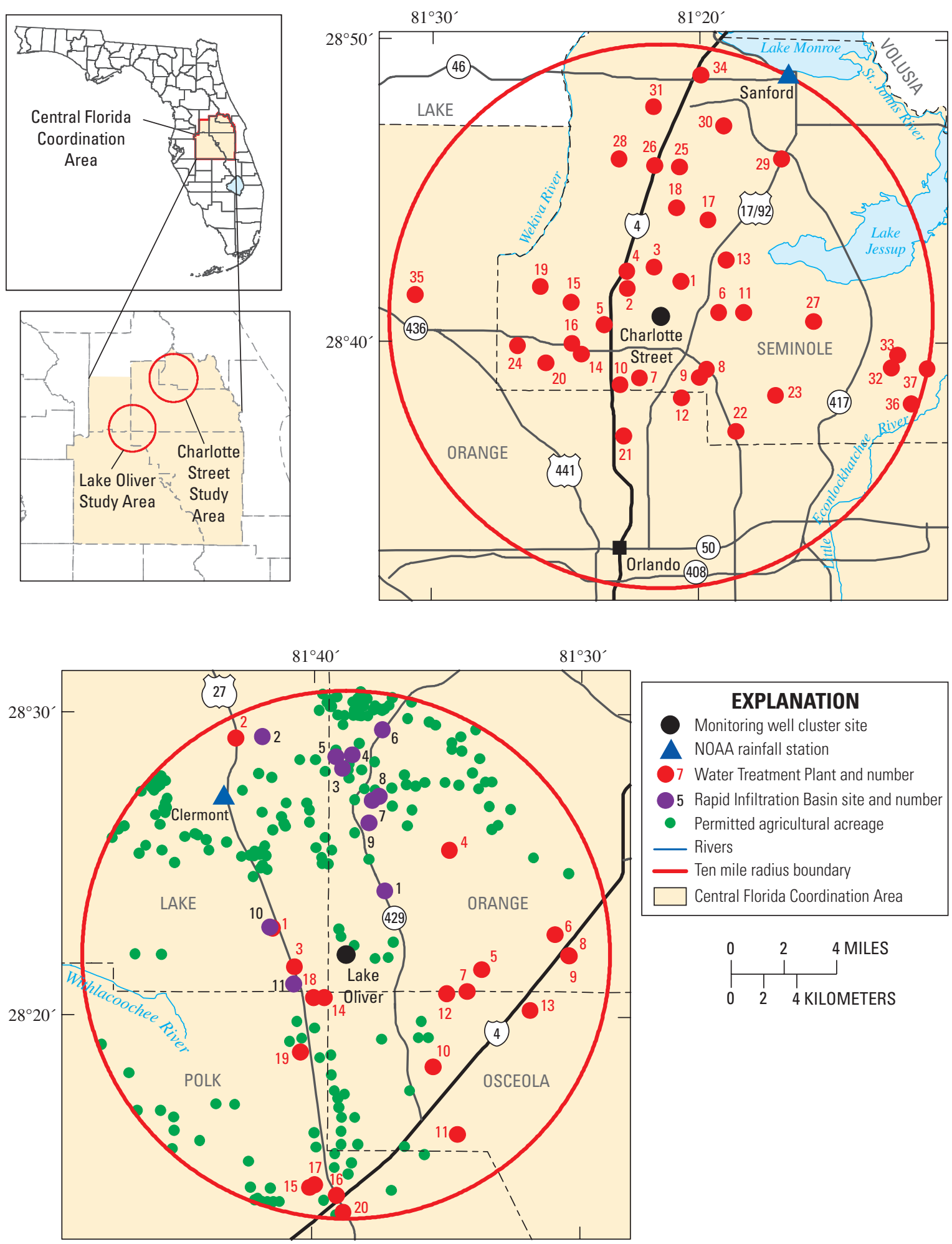

Figure 4. Locations of municipal water-treatment plants, permitted agricultural crop acreages, and rapidinfiltration basins located within 10 miles of the Charlotte Street and Lake Oliver monitoring well sites, 1995-2007. NOAA is National Oceanic and Atmospheric Administration. 

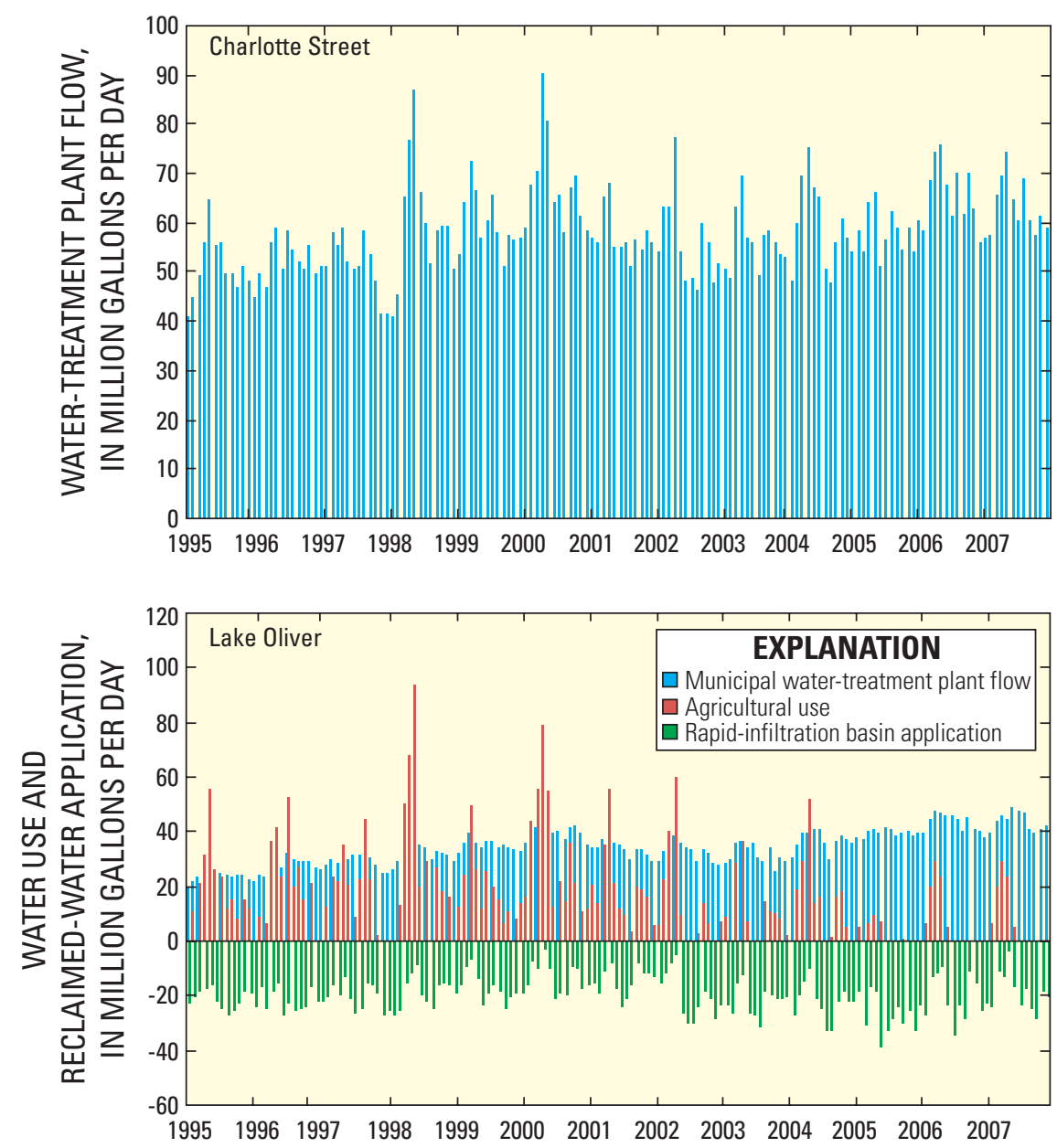

Figure 5. Water use near the Charlotte Street and Lake Oliver monitoring well sites, 1995-2007.

\section{Statistical Methods}

Statistical methods and guidelines described by Helsel and Hirsch (2002) for regression analyses were applied in this study and are discussed in some detail in the following section. A commercially available statistical software package (Minitab 15) was used to perform the analyses. Mean monthly UFA and SAS water levels, and water-level changes, were included as response variables in the analyses. Water-level changes were calculated as the difference between the current month's mean water level and that of the previous month. Explanatory variables included in the analyses are listed on table 1.

Both simple and multivariate linear regression analyses were performed to quantify the relations between the response and explanatory variables. Residuals were examined for normality by examining probability plots, and were plotted against predicted values to assess linearity and uniform scatter (homoscedasticity). No gross violations were observed that would have required log transformation of the response variable. Partial residual plots were examined for linearity and scatter to determine if explanatory variables required log transformation. Explanatory variables were transformed in a few cases, which are noted in respective tables. The DurbinWatson statistic $d_{L}$ (Durbin and Watson, 1951) was used to determine if the time series of monthly water-level residuals and water-level change residuals were serially correlated. Regression analyses using serially correlated data will yield erroneous values for the coefficient of determination $\left(\mathrm{R}^{2}\right)$ and the standard error, and may result in concluding that a statistically significant relation exists between the response and explanatory variables when one does not. Because consecutive monthly values of UFA and SAS water levels were found to be serially correlated ( $d_{L}<1.5$ for $\mathrm{N}=156$ observations), these data had to be parsed for analyses. Based on the Durbin statistic, this turned out to require a grouping of monthly data sets 4 months removed from each other before serial correlation was effectively reduced. Accordingly, regression analyses were conducted on each of the four sets of grouped data. January, May, and September were used in one grouping; February, June, and October were used in a second grouping; March, July, and November were used in a third grouping; and April, August, and December were used in the fourth grouping. 

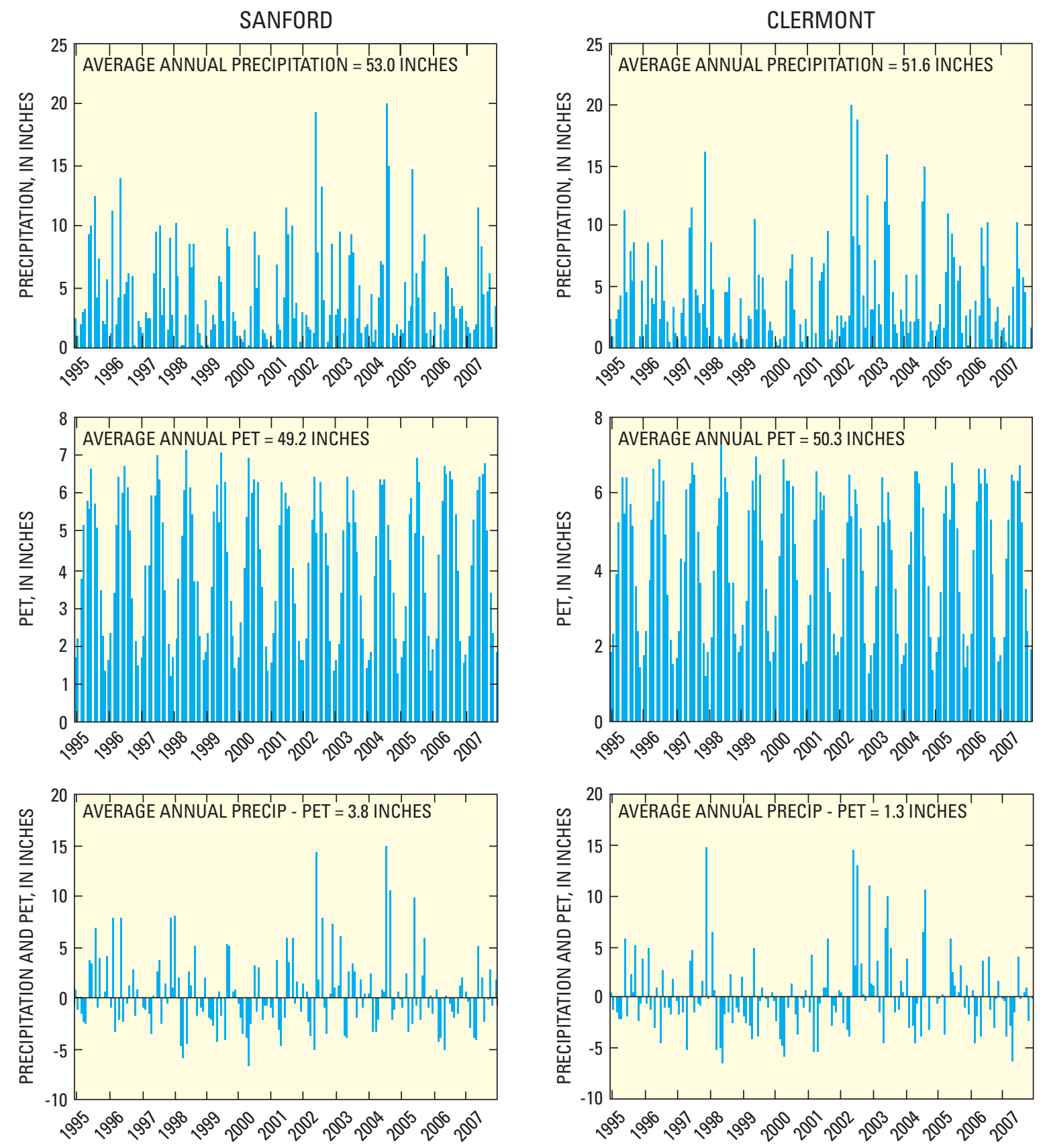

Figure 6. Precipitation, potential evapotranspiration, and difference between precipitation and potential evapotranspiration (PET) at the Sanford and Clermont National Oceanic and Atmospheric Administration rainfall stations, 1995-2007. 


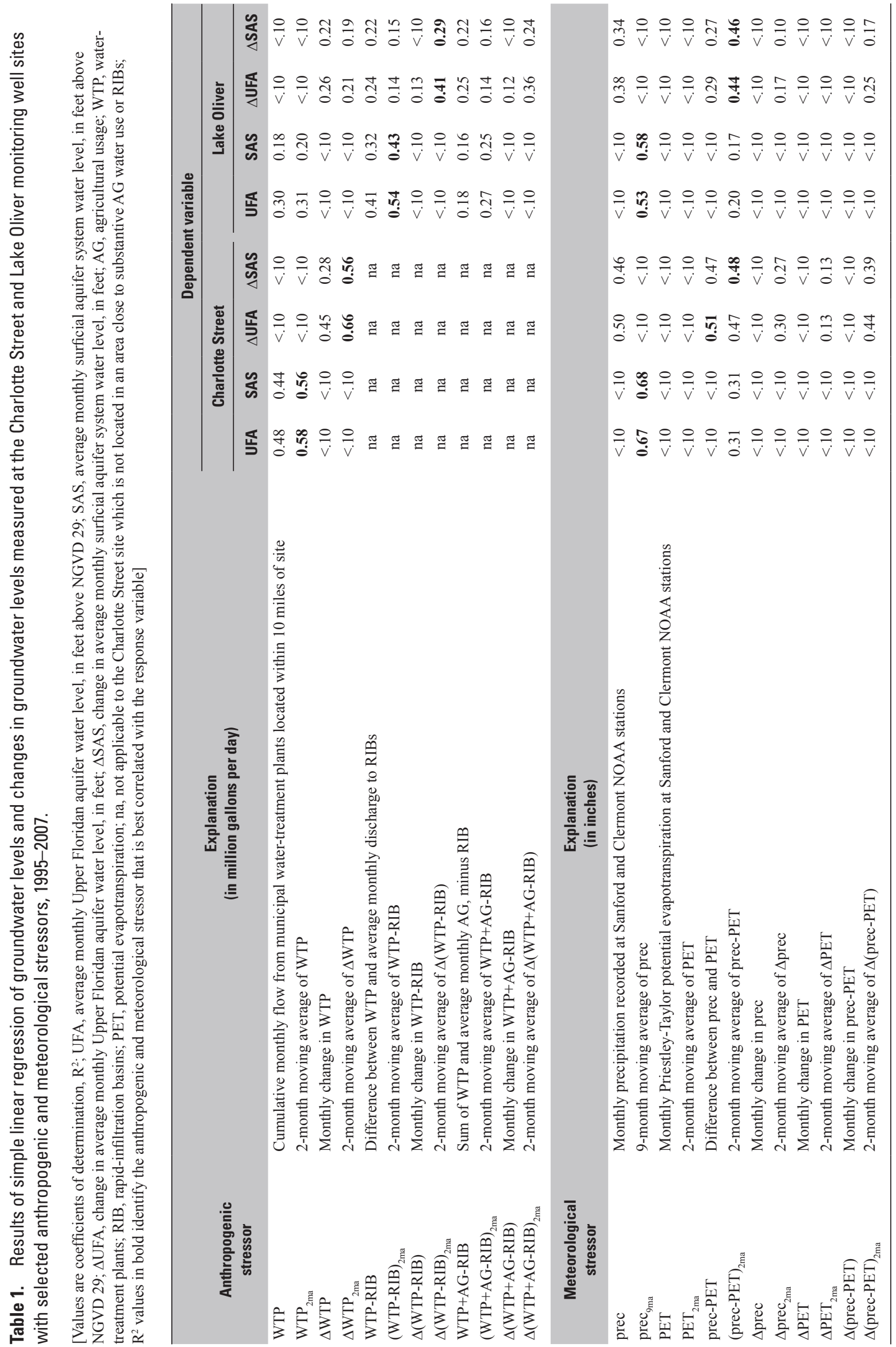


Changes in monthly water levels were not serially correlated and presented the better data set for subsequent analyses; that is, to examine how differences in seasonal conditions and in prolonged wet and dry periods affect results. Finally, regression analyses were performed to examine how the radial distance between points and associated cumulative groundwater withdrawals affect the relations between water-level changes and anthropogenic and meteorological stressors. These radial analyses provide some indication of how important it may be to account not only for the very nearest points of groundwater withdrawals in examining relations, but also for the more regionalized influence of additional and more distant points of withdrawal.

\section{Relation Between Groundwater Levels and Anthropogenic and Meteorological Stressors}

This section presents the results of the regression analyses and discusses the relative influences of anthropogenic and meteorological stressors on groundwater levels at the study sites. Guidelines used to select the "best" models in the multivariate regression analyses are documented.

\section{Simple Linear Regression}

Simple linear regression was performed to (1) identify anthropogenic and meteorological stressors that explained the greatest degree of variance in water levels and water-level changes for inclusion in the multivariate analyses; (2) examine the influence of persistence between response and explanatory variables; and (3) provide comparative results for the multivariate analyses. The term persistence used here refers to the influence of the previous month(s) anthropogenic and meteorological conditions on current monthly water levels or water-level changes.

The 24 explanatory variables listed in table 1 were used in the analyses and included the three variables common to both sites of water-treatment plant flow $(W T P)$, precipitation $(P)$, and potential evapotranspiration (PET). Additionally, three variables were used to account for "net" anthropogenic effects and available water $(W T P-R I B, W T P+A G-R I B$, and $P$-PET). Six variables were used to account for monthly changes in WTP, WTP-RIB, WTP $+A G-R I B, P, P E T$, and $P$-PET, while 12 moving-averaged variables were used to account for persistence of the previously-listed 12 variables. Changes in the moving average of an explanatory variable were determined by first calculating the change in water level from one month to the next, and then calculating the moving average of the monthly changes. Regression results are summarized in table 1 and discussed herein.

Mean monthly water levels and water-level changes in the SAS and UFA were influenced by anthropogenic and meteorological stressors at both sites, though most relations were poor to fair $\left(\mathrm{R}^{2}<0.50\right)$. Water levels were best related with the 9-month moving average of precipitation ( prec $_{\text {gma }_{\text {ma }}}$ ) at both sites, with $\mathrm{R}^{2}$ values ranging from 0.53 for the UFA at Lake Oliver to 0.68 for the SAS at Charlotte Street (fig. 7). Changes in water levels at Charlotte Street were best related to the 2-month moving average of change in WTP flow ( $\mathrm{R}^{2}$ from 0.56 to 0.66 ), while changes in water levels at Lake Oliver were best related to the 2-month moving average of the difference between precipitation and PET ( $\mathrm{R}^{2}$ from 0.44 to 0.46 ) (fig. 8).

Water levels and water-level changes were sensitive to persistence of both stressors, as $\mathrm{R}^{2}$ values could be improved by comparing the response variables with the moving averages of explanatory variables. Moving-average statistics serve to smooth time-series datasets by reducing random variation, thereby revealing underlying trends. Moving-averaged values not only take into account the current month's effect on water levels but those of the previous month(s). For example, the relation between UFA water levels and prec $_{9_{m a}}$ at Charlotte Street was markedly better $\left(R^{2}=0.67\right.$ shown in fig. 7$)$ than that between water levels and the current (single) monthly value of precipitation $\left(\mathrm{R}^{2}<0.010\right.$, not shown). Similarly, the 2-month moving averages of $W T P, W T P-R I B, W T P+A G-R I B, \triangle W T P$, $\Delta(W T P-R I B), \Delta(W T P+A G-R I B),($ prec-PET), $\triangle$ prec, and $\triangle($ prec-PET $)$ all better explained the relation between water levels and/or water-level changes at one or both sites. Accordingly, these moving-average values were included in the set of candidate variables used in the subsequent multivariate analyses.

Monthly values of anthropogenic and meteorological stressors were better related with mean monthly water levels than were changes in monthly stressors. Conversely, changes in water levels were better related with changes in monthly stressor values.

Finally, water levels at Lake Oliver were better related with anthropogenic variables that accounted for more than the effects of just municipal withdrawals. For example, water levels were better related with the 2-month moving average of WTP-RIB $\left(\mathrm{R}^{2}=0.54\right.$ for the UFA), a variable that accounts for the effects of both municipal withdrawals and RIB loadings, than with just the 2-month moving average of WTP $\left(\mathrm{R}^{2}=0.31\right)$. Similarly, water-level changes in the UFA were better related with the 2-month average of change in WTP-RIB $\left(\mathrm{R}^{2}=0.41\right)$ than with the 2-month moving average of change in $W T P\left(\mathrm{R}^{2}=0.21\right)$. Including agricultural withdrawals as an explanatory variable did not improve the regressions.

\section{Multivariate Analyses}

Multivariate linear regression models predict the relation between a response and explanatory variable as

$$
Y=\beta_{0}+\beta_{I} x_{1}+\ldots B_{k} x_{k}+\varepsilon
$$

where $Y$ is the response variable, $\beta_{0}$ is the intercept, $\beta_{1}$ is the slope coefficient for the first explanatory variable $\left(x_{l}\right), B_{k}$ is the slope coefficient for the $\mathrm{k}^{\text {th }}$ explanatory variable $\left(x_{k}\right)$, and $\varepsilon$ is the error or remaining unexplained "noise" in the data. 

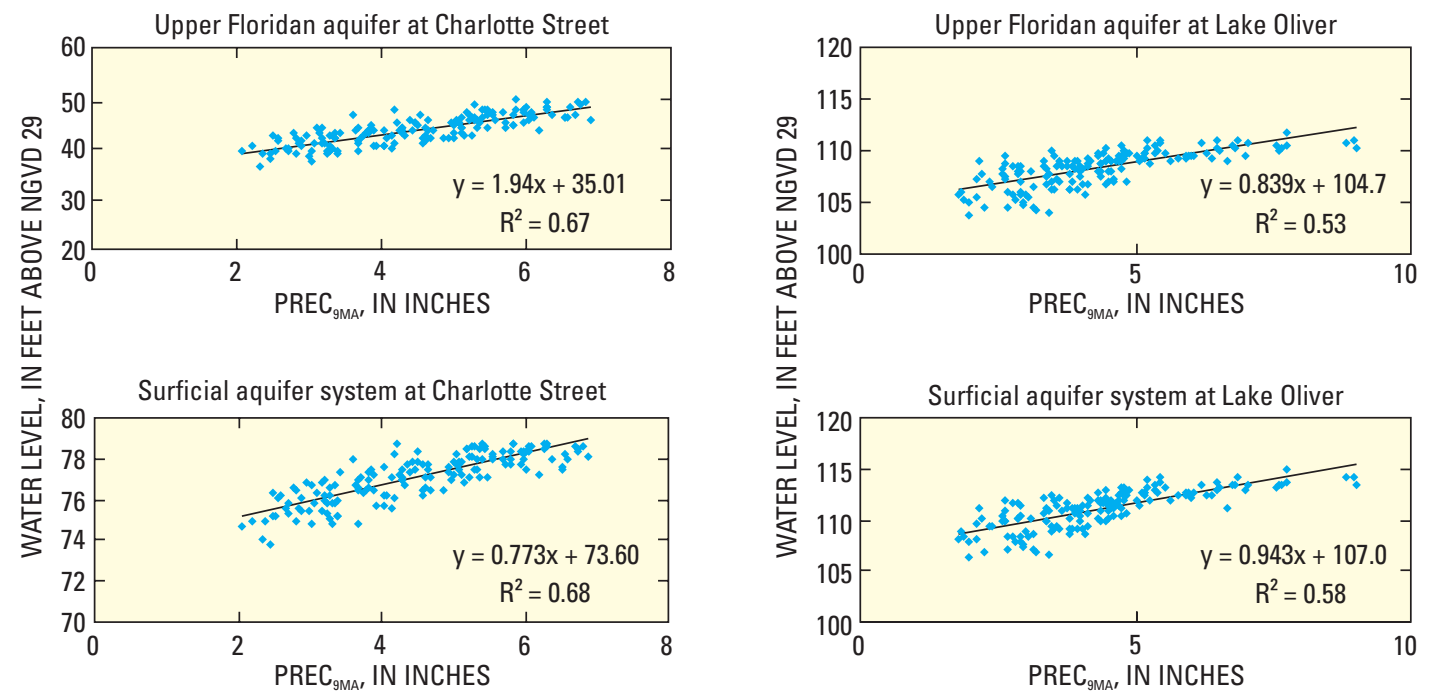

Figure 7. Mean monthly water levels in the surficial aquifer system and Upper Floridan aquifer at the Charlotte Street and Lake Oliver monitoring well sites and the 9-month moving average of precipitation $\left(\mathrm{PREC}_{9 \mathrm{MA}}\right)$ at the Sanford and Clermont National Oceanic and Atmospheric Administration rainfall stations, 1995-2007.

A

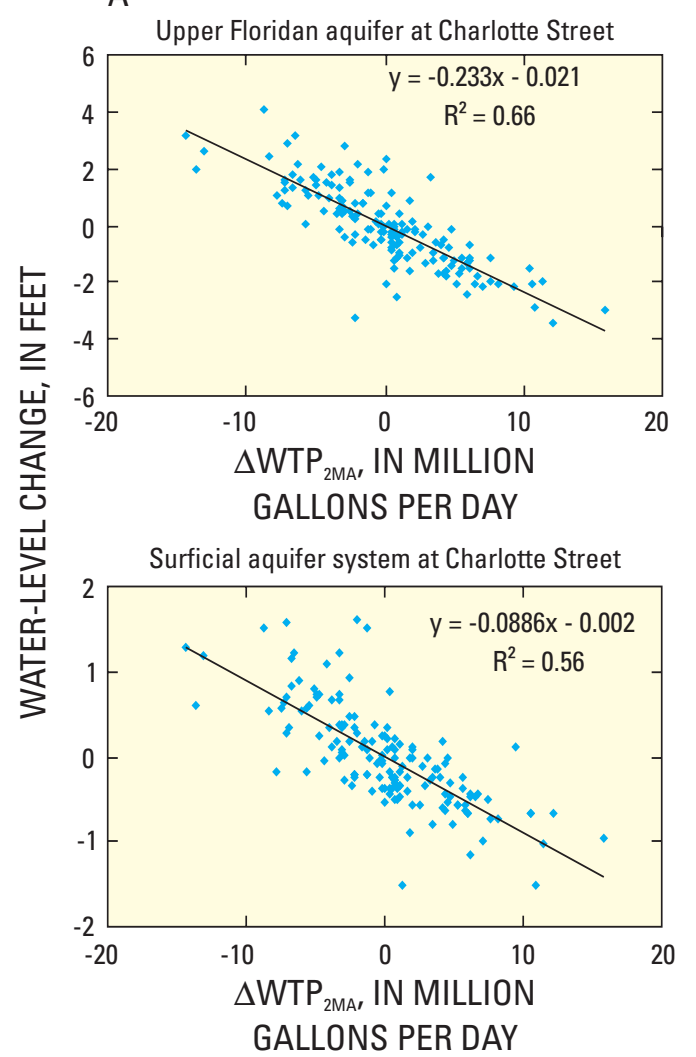

B

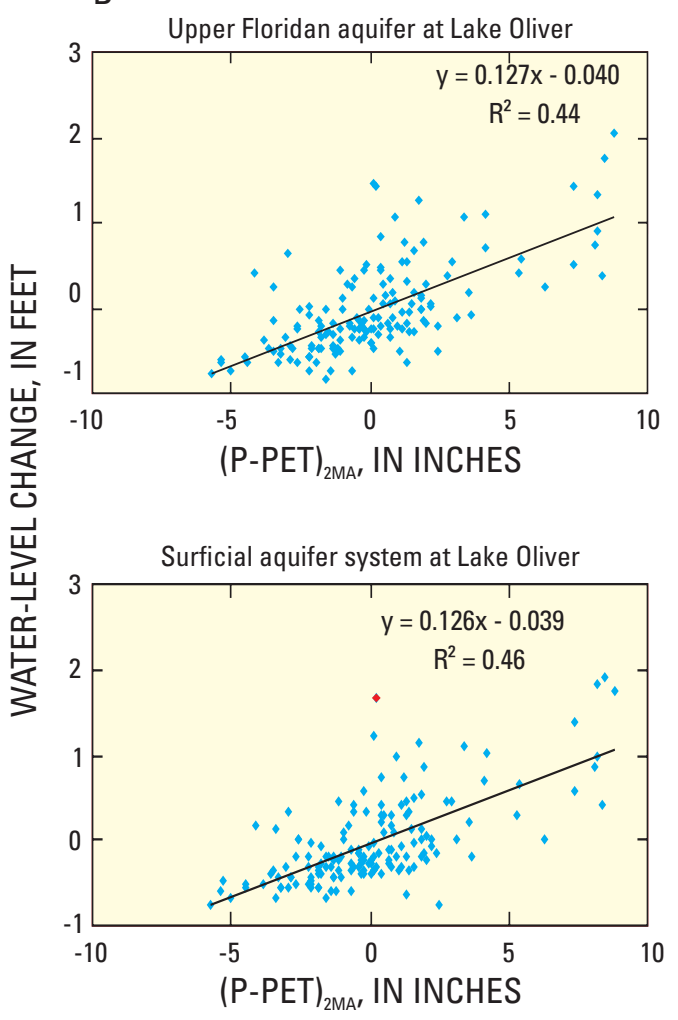

Figure 8. (A) Mean monthly change in surficial aquifer system and Upper Floridan aquifer water levels at the Charlotte Street monitoring well site and the 2-month moving average of change in nearby water-treatment plant flow $\left(\Delta \mathrm{WTP}_{2 \mathrm{MA}}\right)$, and $(\mathrm{B})$ mean monthly change in surficial and Upper Floridan aquifer water levels at the Lake Oliver monitoring well site and the 2-month moving average of the difference between monthly precipitation and potential evapotranspiration (P-PET) ${ }_{2 \mathrm{MA}}$ at the Clermont National Oceanic and Atmospheric Administration rainfall station, 1995-2007. 
Guidelines used to select the "best" models are described by Helsel and Hirsch (2002). Initial model runs were performed using explanatory variables identified in the simple linear regression analyses as having $\mathrm{R}^{2}>0.10$ (table 1 ). The best subsets of models were then identified for each of " $\mathrm{k}$ " explanatory variables, with the "best" model selected by minimizing Mallows $C_{p}$. Mallows $C_{p}$ is a test statistic designed to achieve a compromise between explaining as much of the variance in the response variable as possible by including all relevant explanatory variables, while minimizing the standard error of the resulting estimates by keeping the number of coefficients small. If two best models had equal values of $C_{p}$, the one with the greater $\mathrm{R}_{\text {adj }}^{2}$ was selected. $\mathrm{R}_{\text {adj }}^{2}$ quantifies the proportion of variation in the response data explained by the explanatory variables while accounting for the number of explanatory variables (or equivalently, the degrees of freedom) in the model.

The best selected models were limited to a maximum of three explanatory variables to achieve a compromise between two conflicting objectives of multivariate regression analyses. While one objective is to include as many explanatory variables as possible so that all potential variable influences can be accounted for, a conflicting objective is to include as few variables as possible because the variance of the predicted value increases with the number of explanatory variables (Watts, 1995). All explanatory variables included in the best models had statistically significant slope coefficients ( $p$-value $<0.05$ ). A p-value less than or equal to 0.05 indicates that the probability of a detected correlation or difference not being real is less than 5 percent.

Models containing a variable with a variance inflation factor (VIF) of greater than 3.0 were considered to have unacceptably high levels of multicollinearity and were excluded from consideration. The VIF (Helsel and Hirsch, 2002) is an index that measures how much the variance of a coefficient is increased because of multicollinearity. The value of 3.0 used in these regressions was arbitrarily selected to provide a more rigorous benchmark for identifying unacceptable levels of multicollinearity than the value of 10 recommended by Helsel and Hirsch (2002).

Models with explanatory variables having nonsensical slope coefficients were excluded, even though such models may have provided lower $C_{p}$ values. For example, several models included PET as a significant variable, but indicated that PET was directly, and not inversely, related to water levels or water-level changes as would be expected. Nonsensical relations such as these likely can be attributed to multicollinearity between PET and one of the other included variables, such as precipitation, even though VIF values may be acceptably low (Dennis Helsel, U.S. Geological Survey, retired, written commun., April 2009). PET and precipitation are both greatest in the warm summer months, yet the two parameters work in opposite directions in terms of their effects on groundwater levels.

Regression results are summarized in a series of tables that identify the explanatory variables included in the best models, the equation intercept values, the variable slope coefficients, and the variable $p$-values. The variable $p$-value not only indicates whether a given explanatory variable is statistically correlated with the response variable, but also was used to interpret the results in terms of the relative influence of anthropogenic and meteorological stressors on water levels and water-level changes. In a two-variable model, for example, the variable with the smaller p-value would be more closely associated with the response variable than would the variable with the higher $\mathrm{p}$-value. In cases where both variables had p-values of less than 0.001 , which is the lower limit reported by the Minitab software package used in these analyses, the response variable was considered to be highly correlated with, and equally sensitive to, both variables.

\section{Monthly Analyses}

Results of the monthly analyses of water levels, and changes in water levels, are summarized for the Charlotte Street and Lake Oliver sites in tables 2 and 3, respectively. Relative to the simple linear regression results, relations between response and explanatory variables were markedly improved in the multivariate analyses, with $\mathrm{R}_{\text {adj }}^{2}$ values ranging from 0.59 to 0.82 . Based on comparison of variable p-values, and as indicated under the "relative influence of stressor" column, UFA water levels at Lake Oliver were better related with anthropogenic stressors than with meteorological stressors (table 3), while those at Charlotte Street tended to be better related with meteorological stressors (table 2). SAS water levels, on the other hand, were better related with meteorological stressors at both sites. With one exception, both UFA and SAS water levels at Charlotte Street were best related with prec $_{9_{m a}}$, while SAS water levels were best related with prec $_{9_{m a}}$ at Lake Oliver.

Changes in UFA water levels tended to be equally related with the two stressors at both sites. Similarly, changes in SAS water levels were equally related with both stressors $\left(\triangle W T P_{2 m a}\right.$ and prec) at Charlotte Street, but were more highly related with meteorological stressors (prec and $\Delta$ prec) at Lake Oliver (table 2). At Lake Oliver, changes in UFA water levels were again best related with a variable that measures net anthropogenic effects $\left(\triangle(W T P-R I B)_{2 m a}\right)$; in this case, results suggest that recharge from RIBs may influence changes in these water levels, at least for the averaged conditions represented by the 13-year period of record. Variables which included agricultural withdrawals did not markedly improve relations with water levels or water-level changes at Lake Oliver.

Examples of partial residual plots of changes in water levels and explanatory variables, typical of those examined throughout these regression analyses, are shown in figure 9. Partial residuals plots depict the relation between each of the explanatory variables and the response variable in the multivariate regression equation. The slope of these plots and the scatter of the data indicate whether results make sense and conform to assumptions inherent in the regression analyses. At Lake Oliver, changes in UFA water levels are inversely related to $\Delta(W T P-R I B)_{2 m a}$ and $\Delta p r e c$, as would be expected, 


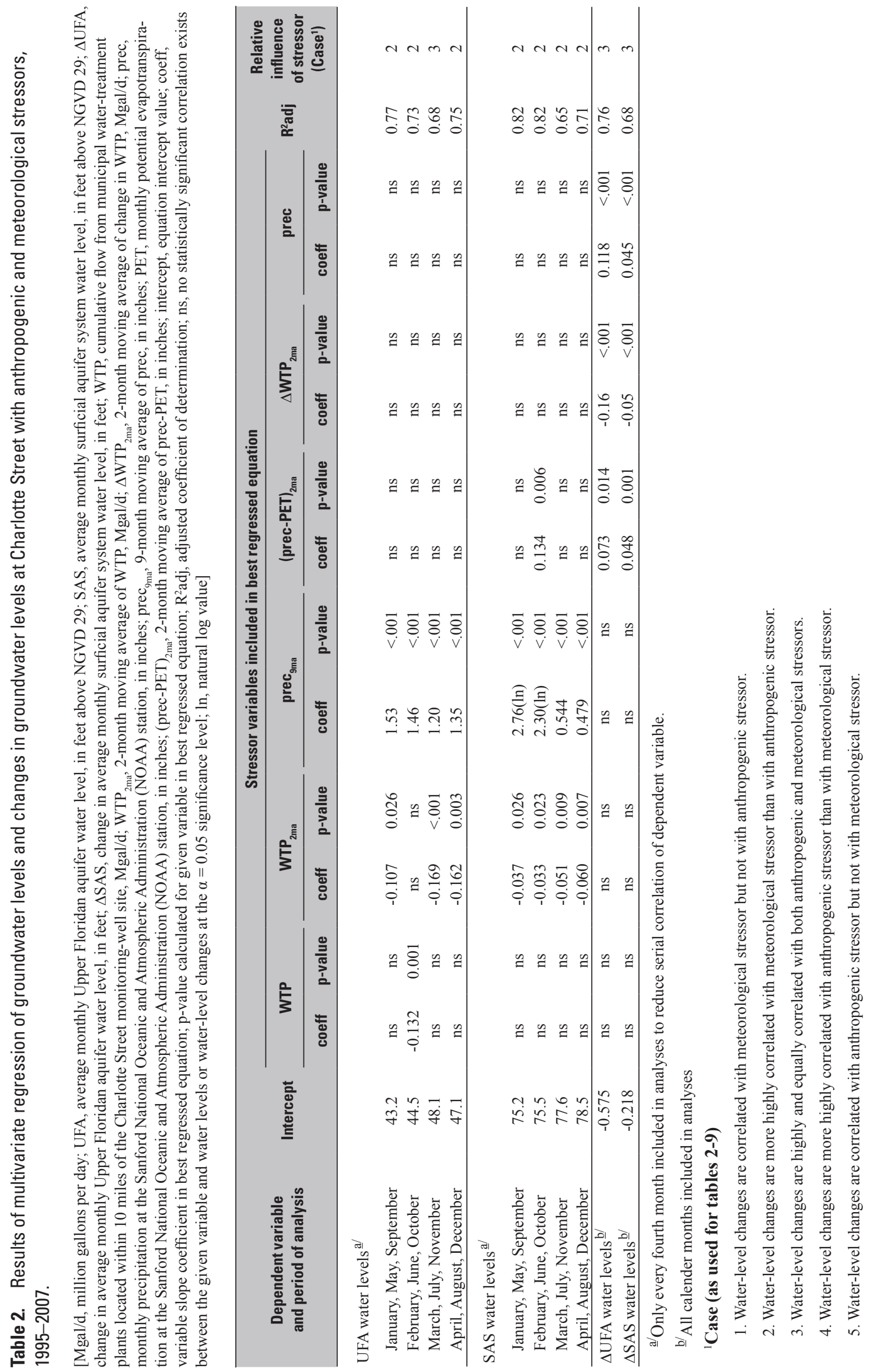




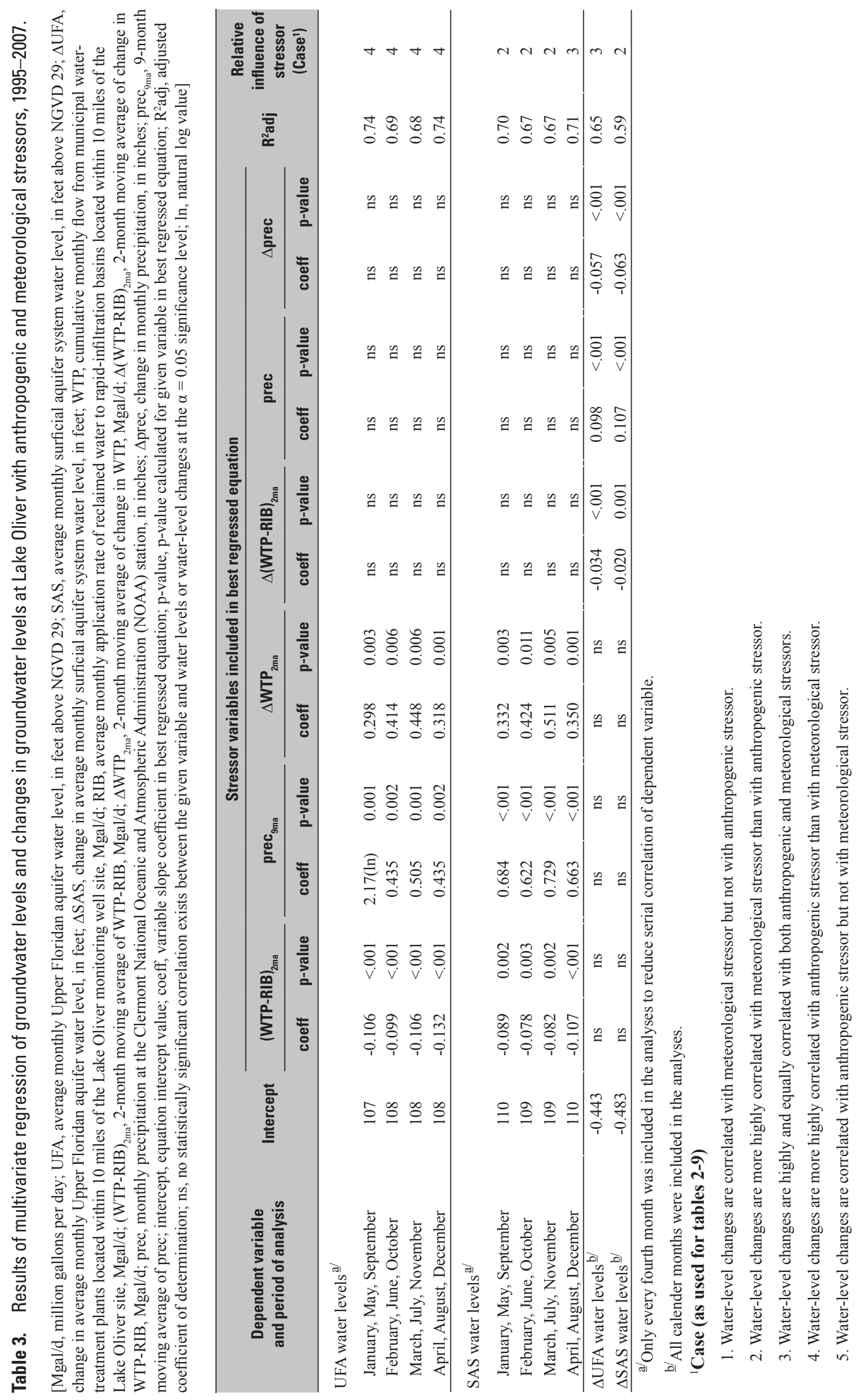



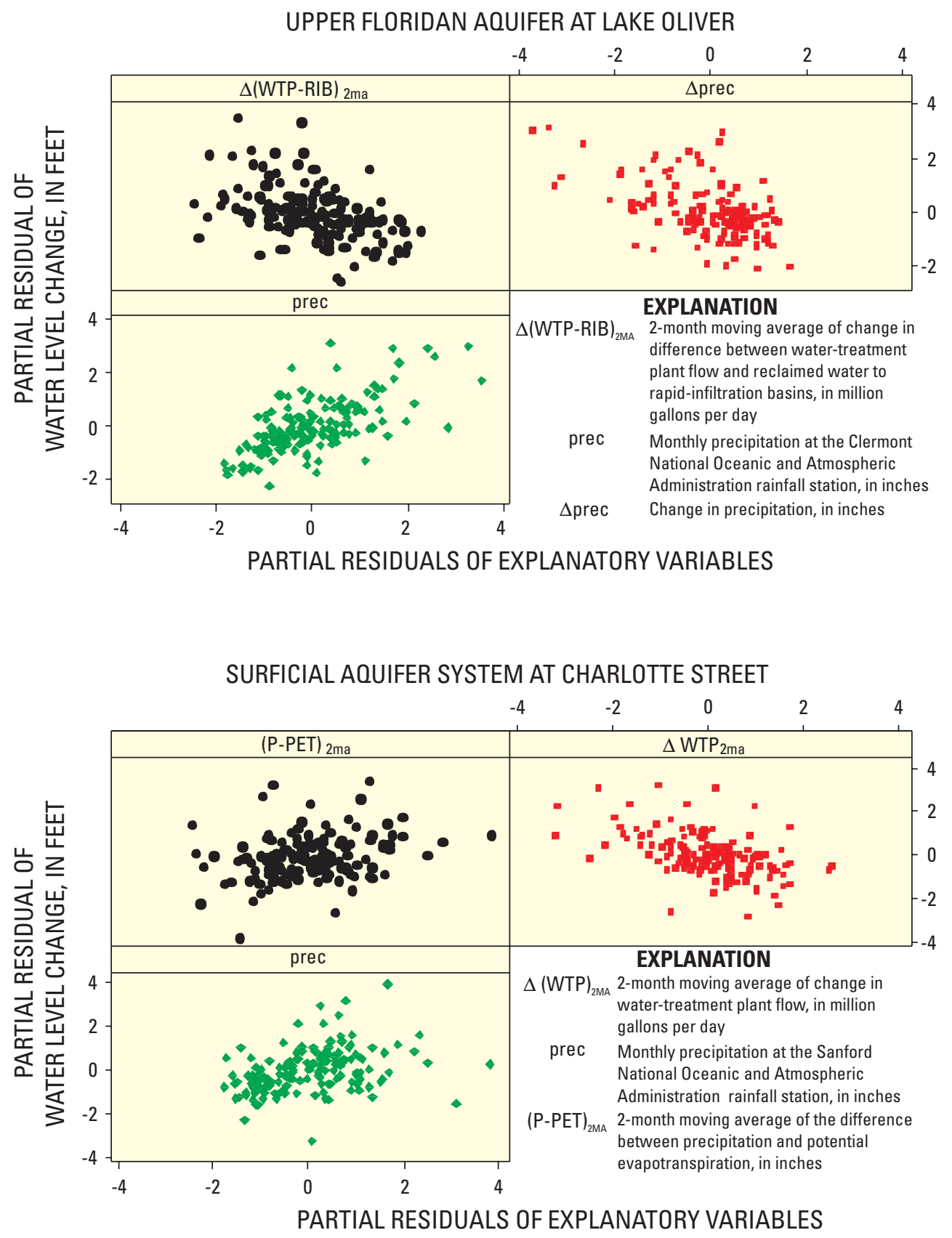

Figure 9. Standardized partial residuals of mean monthly changes in Upper Floridan aquifer and surficial aquifer system water levels and explanatory variables in best regressed equations, 1995-2007.

and directly related to prec. Similarly, changes in SAS water levels at Charlotte Street are inversely related to $\triangle W T P_{2 m a}$ and directly related to prec and $(P-P E T)_{2 m a}$. With few exceptions, the partial residual plots examined throughout these analyses indicated no gross violation of assumed model linearity or homoscedasticity.

While precipitation and the difference between precipitation and PET were included as explanatory variables in many of the best regression models, none of the models included PET as a single explanatory variable. This apparent insensitivity of water-level changes to PET likely is due to the fact that PET is not a true measure of actual evapotranspiration, which may be considerably less. Actual evapotranspiration may have been a better explanatory variable to use in these regressions because it provides a more accurate estimate of the amounts of precipitation lost to the SAS, particularly in areas having deep water tables such as Lake Oliver. Unfortunately, estimates of actual evapotranspiration required more detailed information that was not readily available at the study sites. 


\section{Seasonal Analyses}

The relations discussed thus far represent those for averaged anthropogenic and meteorological stressor conditions. In fact, these relations are dynamic and likely change with variations in stressor conditions that occur on a seasonal basis. The results of regressions performed to examine seasonal differences are summarized in tables 4 and 5 . The analyses were conducted on months grouped by season: that is, for January, February, and March (winter); April, May, and June (spring); July, August, and September (summer); and October, November, and December (fall). Thus, each seasonal analysis included 39 observations for the 13-year period of record.

Seasonal variations in groundwater withdrawals and precipitation affected the relative influences of anthropogenic and meteorological stressors on changes in groundwater levels at both sites. While water-level changes tended to be equally related with the two stressors across the entire 13 -year period of record (tables 2 and 3), changes tended to be more influenced by one stressor or the other on a seasonal basis. Overall, water-level changes in the UFA tended to be more closely associated with anthropogenic stressors while changes in the SAS were better associated with meteorological stressors.

At Charlotte Street, changes in UFA water levels were more influenced by meteorological stressors only during the winter months, when municipal withdrawals were minimized (monthly mean of $54.1 \mathrm{Mgal} / \mathrm{d}$ ), but were more influenced by withdrawals in the spring when this stressor peaked (monthly mean of 65.8 . Mgal/d) (table 4). Changes in SAS water levels, however, were solely or more highly related to meteorological stressors in the winter, spring, and summer months, and were equally related with anthropogenic and meteorological stressors in the fall.

At Lake Oliver, changes in UFA levels were more influenced by groundwater withdrawals than by precipitation for all but the winter season, and were influenced solely by withdrawals in the summer (table 5). While drawdown produced from large increases in withdrawals between winter and spring probably accounts for the association between this stressor and water-level changes in the spring, the exclusive association between summer water-level changes and withdrawals is probably due to the recovery in UFA water levels that occurred as withdrawals were reduced from an average of $55.7 \mathrm{Mgal} / \mathrm{d}$ in the spring to $22.8 \mathrm{Mgal} / \mathrm{d}$ in the summer. Changes in SAS water levels at Lake Oliver were better related to meteorological stressors across all seasons.

With the exception of changes in SAS water levels in the summer, water-level changes at Charlotte Street were relatively insensitive to PET. The seasonal timing of this correlation makes sense in that PET is greatest in the warm summer months when it would be expected to exert the most influence on SAS water levels. Also, this site is located in a wetland environment where the water table was within 1 to $5 \mathrm{ft}$ below land surface across the 13-year period of record, as compared with 3 to $11 \mathrm{ft}$ below land surface at Lake Oliver. Thus, PET measured at Charlotte Street is probably a better estimator of the amount of water actually evapotranspired back into the atmosphere than was PET at Lake Oliver. Actual evapotranspiration, as opposed to PET, would be best associated with SAS water-level changes.

Change in the 2-month moving average of municipal withdrawals was the most common anthropogenic stressor included in the best models at Charlotte Street. At Lake Oliver, most of the best models included the 2-month moving average of either municipal withdrawals or the difference between municipal withdrawals and RIB applications. Several models at Lake Oliver included agricultural withdrawals in the stressor term.

Anthropogenic and meteorological stressors explained between 40 and 87 percent of variance in seasonal UFA and SAS water-level changes (tables 4 and 5). Greatest $\mathrm{R}_{\text {adj }}$ values were obtained for the spring season, while lowest values were obtained for the winter or summer months. In general, more of the variance in water-level changes could be explained by the stressor variables at Charlotte Street than at Lake Oliver, possibly because the magnitudes of water-level change at the former are greater than those at the latter and may thus be less affected proportionally by error or noise in the data.

\section{Wet and Dry Period Analyses}

The seasonal analyses discussed above account for relatively short-term periods of varying anthropogenic and meteorological stressor conditions. Accordingly, results are not as useful for contrasting the influences of these stressors on changes in water levels during more extended wet or dry hydrologic conditions that may endure for months, or even years, such as the drought that occurred in central Florida between 1998 and 2001.

This section describes the results of analyses to examine the relative influences of anthropogenic and meteorological stressors on changes in UFA and SAS water levels during extended periods of hydrologic extreme between 1995 and 2007. Periods of record selected for these analyses were identified from long-term (1931-2007) cumulative rainfall departures curves developed for the Sanford and Clermont NOAA rainfall stations (fig. 10). The slopes depicted in these plots are useful for identifying extended wet and dry hydrologic conditions. A rising slope, for example, identifies a period of aboveaverage rainfall whereas a declining slope reflects belowaverage rainfall. When applied to the 13-year period of record examined in this study, several distinctly wet and dry periods could be identified for analyses. For comparative purposes, each selected period spans at least 12 months with an average slope of at least plus or minus $1.0 \mathrm{in}$. of rainfall departure per month. Wet periods examined in these analyses range from 12 to 27 months at the Sanford NOAA station (for Charlotte Street) and from 13 to 17 months at the Clermont station (for Lake Oliver). Dry periods selected for analyses range from 18 to 40 months at the Sanford station and from 12 to 51 months at the Clermont station. 


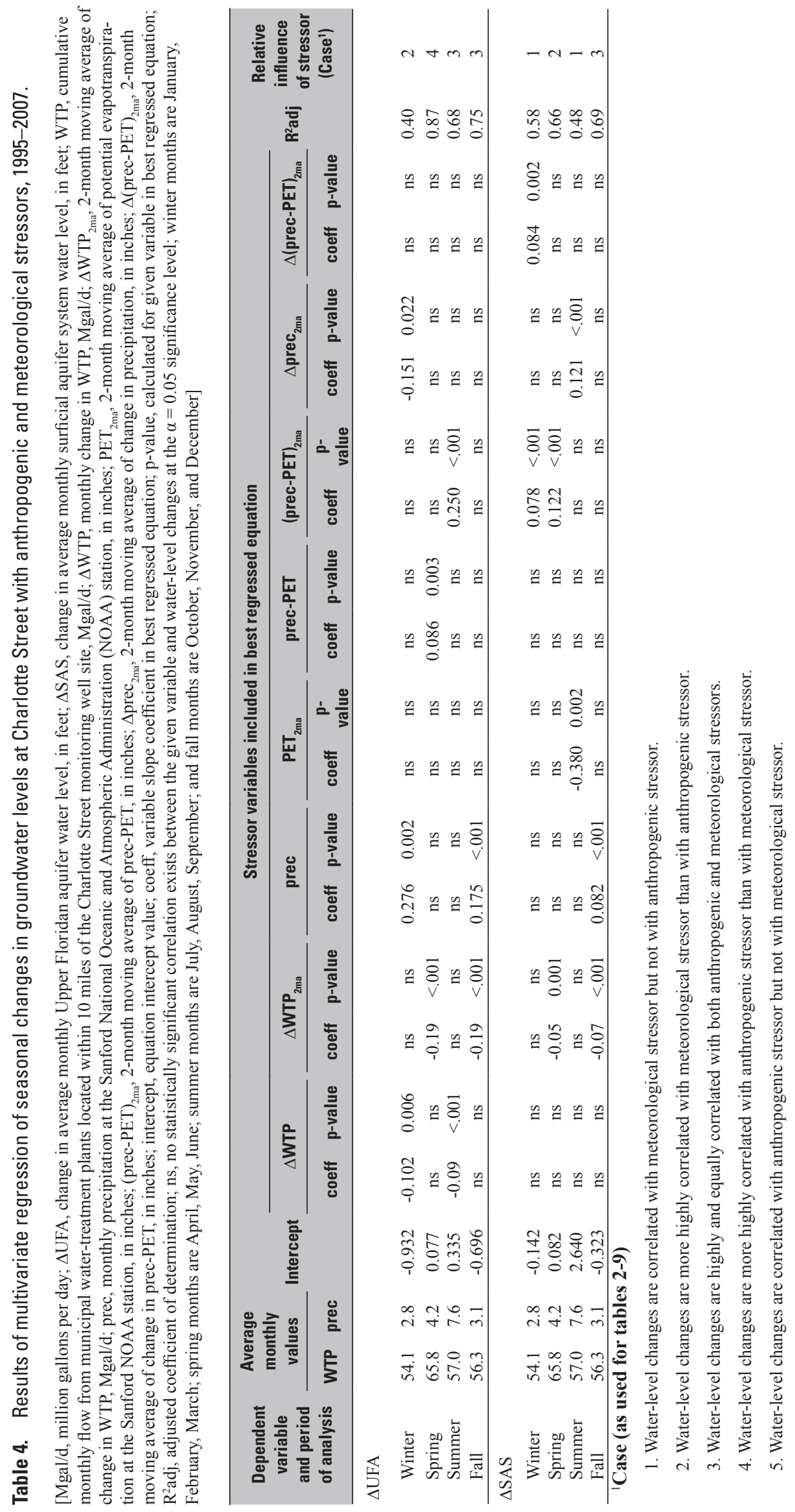




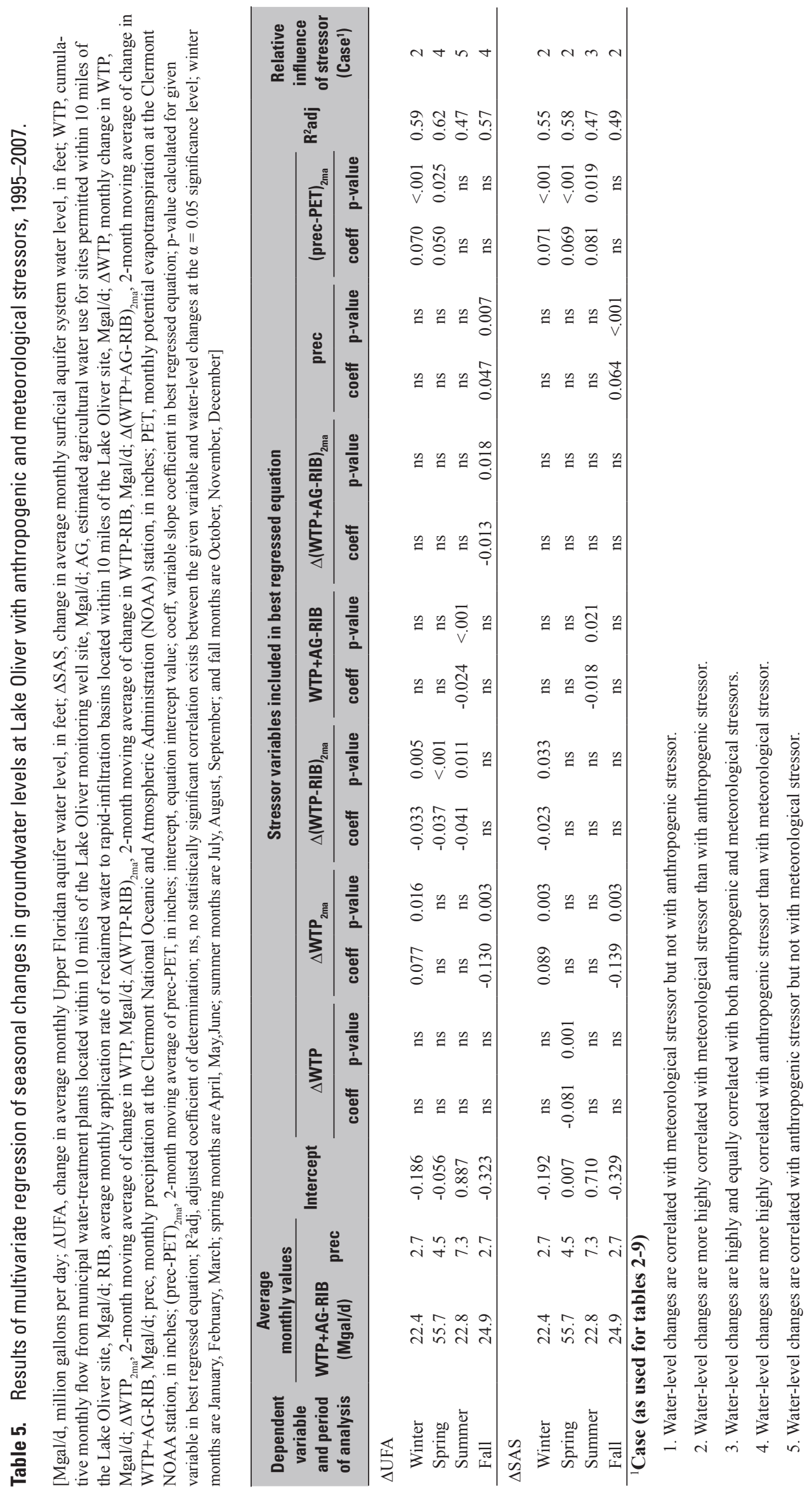



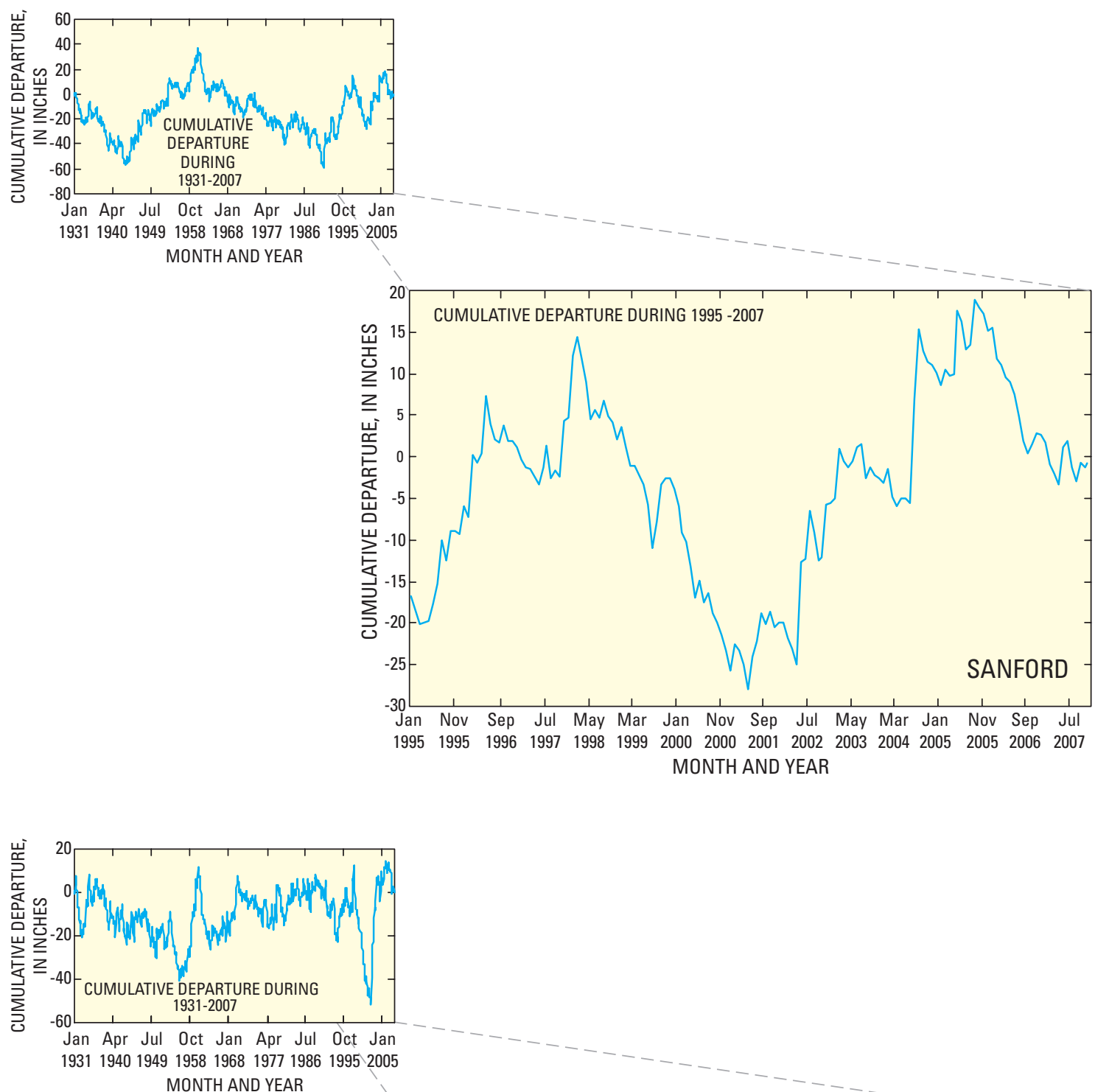

MONTH AND YEAR

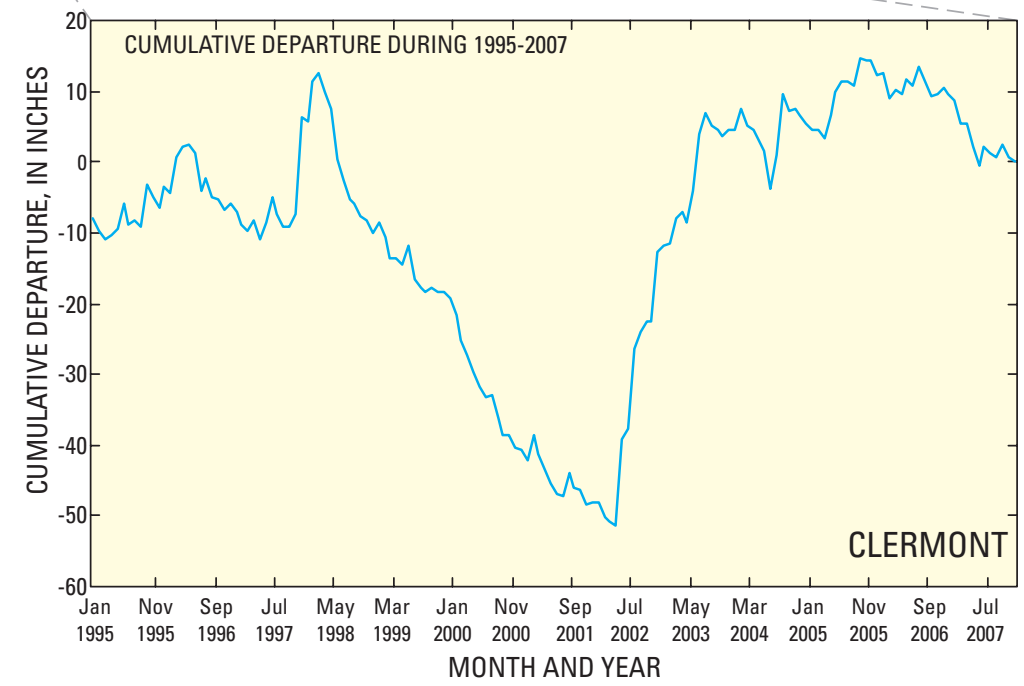

Figure 10. Cumulative departure from long-term (1931-2007) average rainfall at the Sanford and Clermont NOAA rainfall stations. 
While changes in water levels tended to be equally related to anthropogenic and meteorological stressors across the entire 13-year period of record (tables 2 and 3), changes in water levels were, for the most part, more closely related with one or the other stressors during extended wet and dry periods (tables 6 and 7). These results again reflect the dynamic nature of the relations between changes in water levels and these stressors, which are largely dependent upon the relative magnitudes of groundwater withdrawals and precipitation.

As reflected by variable p-values, changes in UFA water levels at Charlotte Street during extended dry periods of record were more influenced by groundwater withdrawals, while changes in SAS water levels were more influenced by meteorological stressors. At Lake Oliver, changes in both UFA and SAS water levels were better related to meteorological stressors for all but the wet period between April 1995 and April 1996. Interestingly, changes in both UFA and SAS water levels were better related to anthropogenic stressors during the wet periods between April 1995 and June 1996 at Charlotte Street and between April 1995 and April 1996 at Lake Oliver. A possible explanation for this relation has been previously discussed; that is, reductions in groundwater withdrawals that typically occur during wetter periods of record can result in appreciable recovery of both UFA and SAS water levels.

With one exception, anthropogenic and meteorological stressors explained between 62 and 89 percent of variance in UFA and SAS water-level changes during periods of hydrologic extreme. In general, $\mathrm{R}_{\text {adj }}^{2}$ values determined for the wet and dry periods examined here were greater than those previously documented for the more hydrologically averaged conditions represented by the entire 13-year period of record between 1995 and 2007 (tables 2 and 3). A possible explanation for the greater $\mathrm{R}_{\text {adj }}^{2}$ values may be that, as one or the other stressors become more dominant during periods of hydrologic extreme (i.e., high withdrawals during the spring), that stressor tends to explain more of the variance in the response variable than it did over the averaged 13-year period of record when it was less dominant.

\section{Evaluation of Regional Pumpage Effects}

The analyses discussed thus far have accounted for the cumulative effects of all groundwater withdrawals and RIB applications located within $10 \mathrm{mi}$ of the study sites. In contrast, the analyses discussed below examine the effects of accounting for withdrawals from just the closest wellfield, and how relations are influenced by radially dependent increases in cumulative withdrawal rates at distances greater than that of just the nearest well fields. Accordingly, analyses were conducted across the 13-year period of record for cumulative anthropogenic stressor values located within 2, 2.5, 3, 4, 5, 7, and $10 \mathrm{mi}$ of the Charlotte Street site (table 8 ) and within 2, 3, 4, 5, 6, 8, and $10 \mathrm{mi}$ of the Lake Oliver site (table 9).

Accounting for the regional effects of anthropogenic stressors had limited influence on water-level changes at Charlotte Street and virtually no influence on changes at Lake Oliver. At Charlotte Street, when regressed against just the 2.2 Mgal/d of withdrawals located within $2 \mathrm{mi}$ of the site, water-level changes were influenced solely by precipitation and PET. At a radius of $2.5 \mathrm{mi}$, however, where cumulative withdrawals increased to about $9.5 \mathrm{Mgal} / \mathrm{d}$, water-level changes were equally influenced by groundwater withdrawals and meteorological stressors. Accounting for withdrawals beyond a 3-mi radius had no appreciable effect on the relation between water-level changes and these stressors, given that variable $\mathrm{p}$-values remained less than 0.001 for both stressors and that $\mathrm{R}_{\text {adj }}^{2}$ values were only nominally improved.

Changes in water levels at Lake Oliver were not influenced by radially dependent cumulative increases in groundwater withdrawals, at least not within the scope of these regression experiments. At all distances, UFA levels were influenced equally by anthropogenic and meteorological stressors, while SAS levels were more closely associated at all distances with meteorological stressors. The most influential anthropogenic stressor variables include some combination of municipal withdrawals, agricultural withdrawals, and RIB applications. The most influential meteorological stressors were precipitation and change in precipitation. It is again worthwhile noting that, unlike results at Lake Oliver, the meteorological parameters best associated with water-level changes at Charlotte Street included PET as a factor. As previously discussed, the difference between precipitation and PET probably provides a more realistic estimate of true water availability at Charlotte Street, which is located in a wetland environment, than does the difference at Lake Oliver where the water table is considerably deeper.

\section{Sources of Error}

Virtually all regression models of environmental data contain some level of unexplained noise or error (the $\varepsilon$ term in eq. 1). Based on the values of $\mathrm{R}_{\text {adj }}^{2}$ documented here, and depending on the particular type of analyses conducted, anywhere from 10 to 60 percent of the variance in the response variable could not be explained by the best regression model. This error can be attributed to a combination of numerous factors that may involve anything from data-related errors to exclusion of other pertinent explanatory variables that affect water levels.

Data-related errors may include inaccuracies in specified water-use rates, particularly for agricultural use, because these rates were theoretically derived and not explicitly measured. The amounts of precipitation in east-central Florida can vary appreciably over relatively short distances and, as a result, precipitation measured at the Sanford and Clermont NOAA rainfall stations may vary somewhat from the amounts received locally at the Charlotte Street and Lake Oliver monitoring well sites, particularly during the summer months. Also, actual evapotranspiration may have been a superior parameter than PET to use in these analyses because it provides a more accurate measure of the amounts of water actually lost from the SAS, and thus of true water availability, when subtracted from precipitation. Water levels and water-level changes at both sites were found to be insensitive to PET as a single parameter, but were significantly correlated with the difference between precipitation and PET at Charlotte Street. 


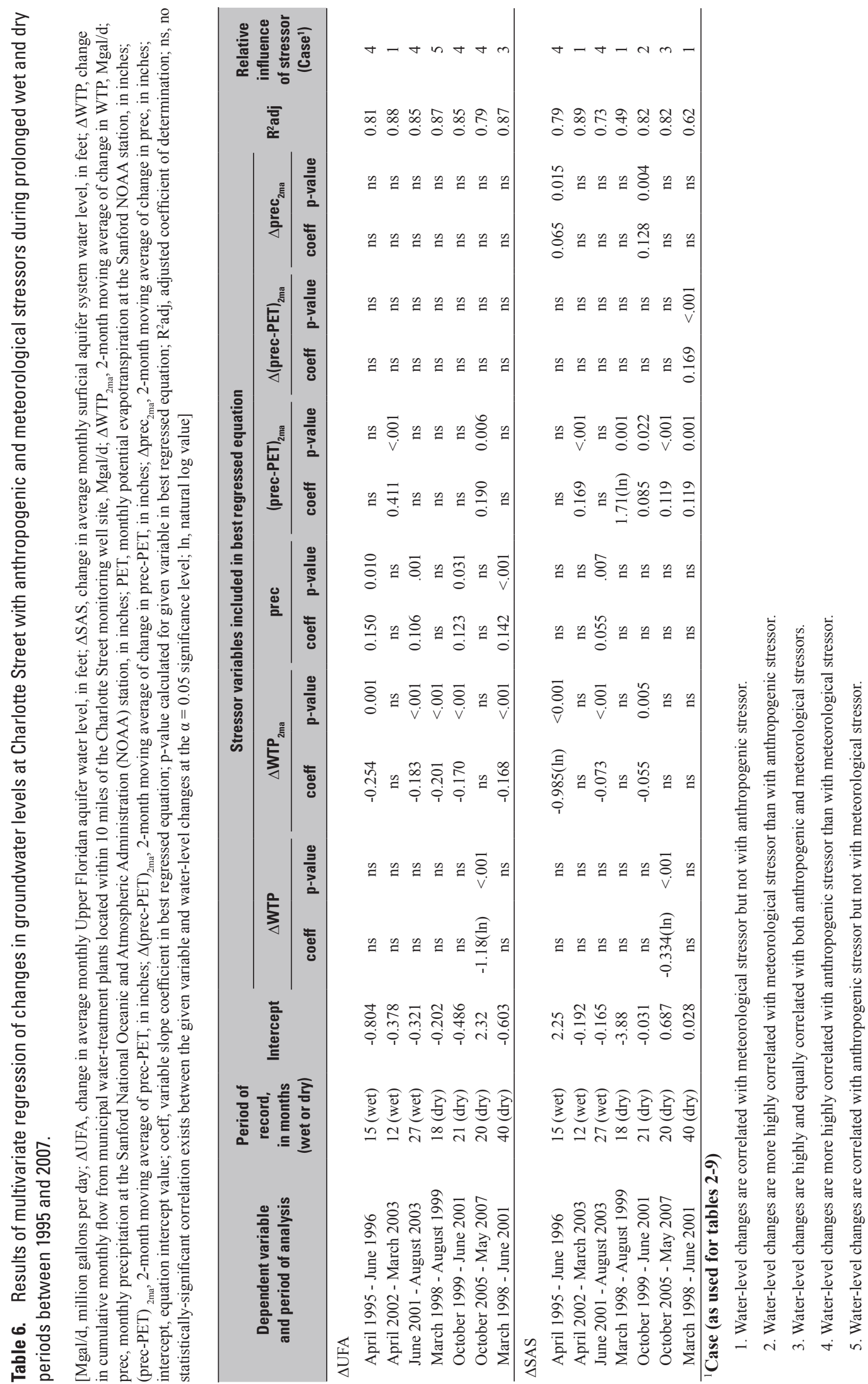




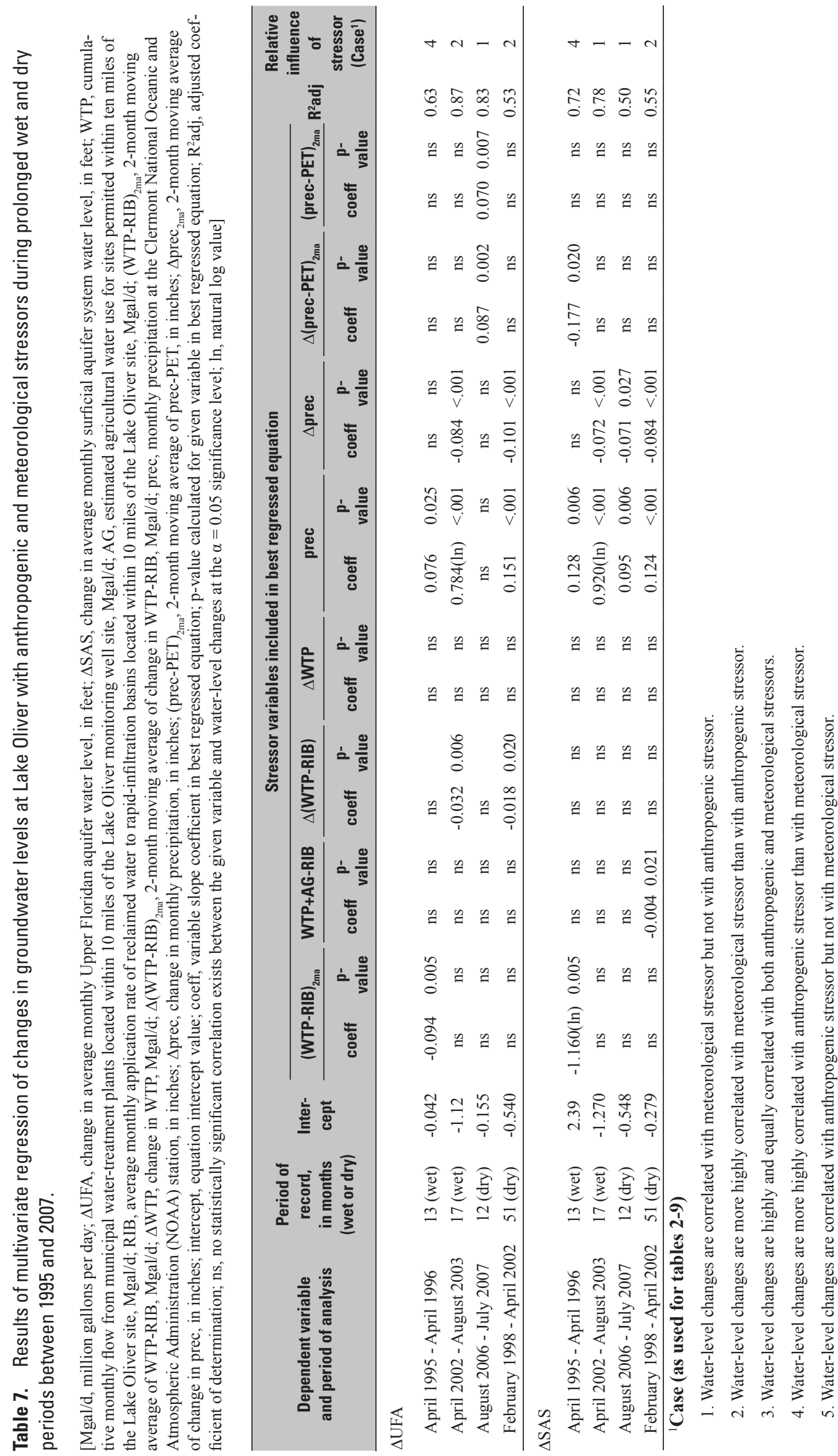




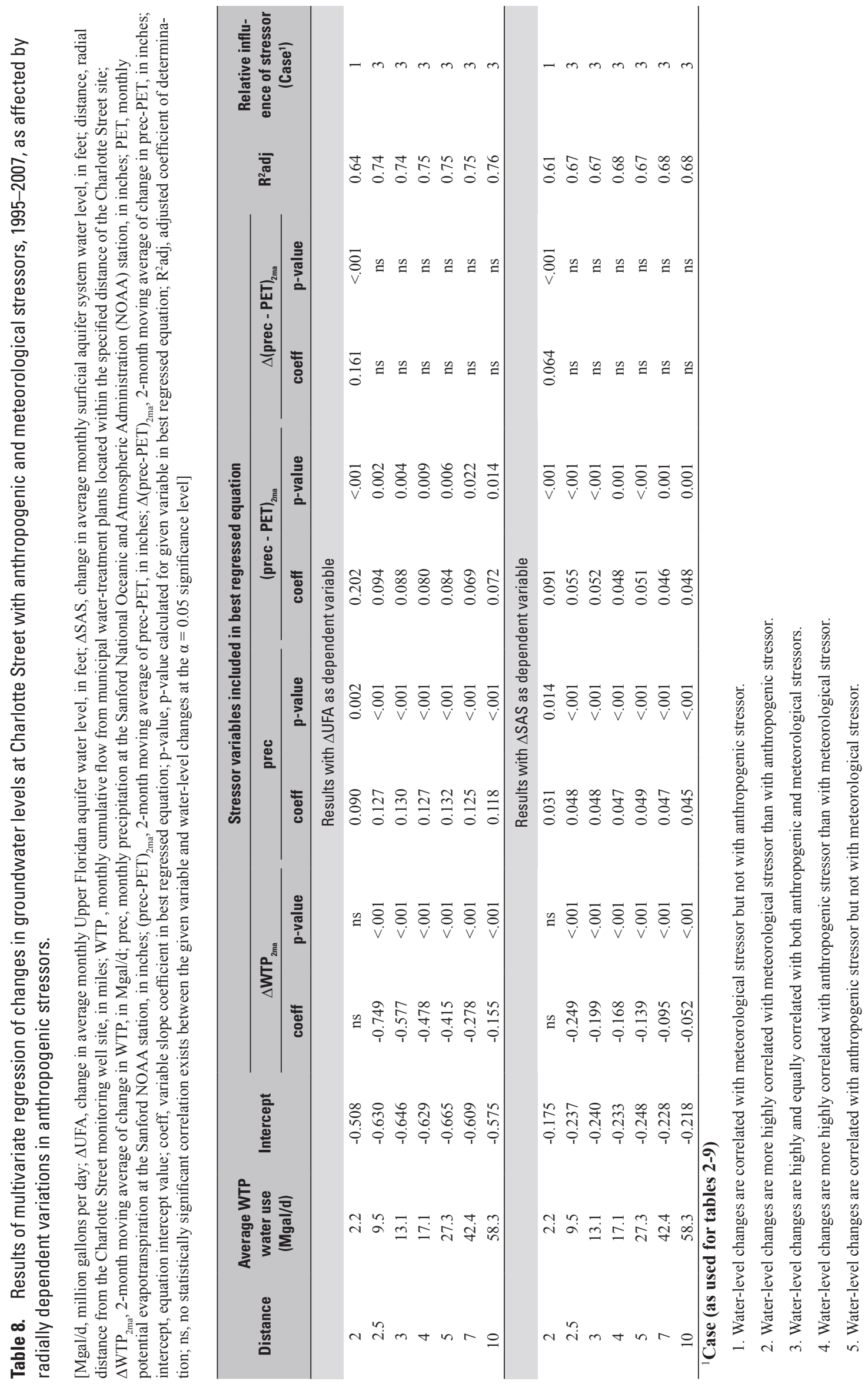



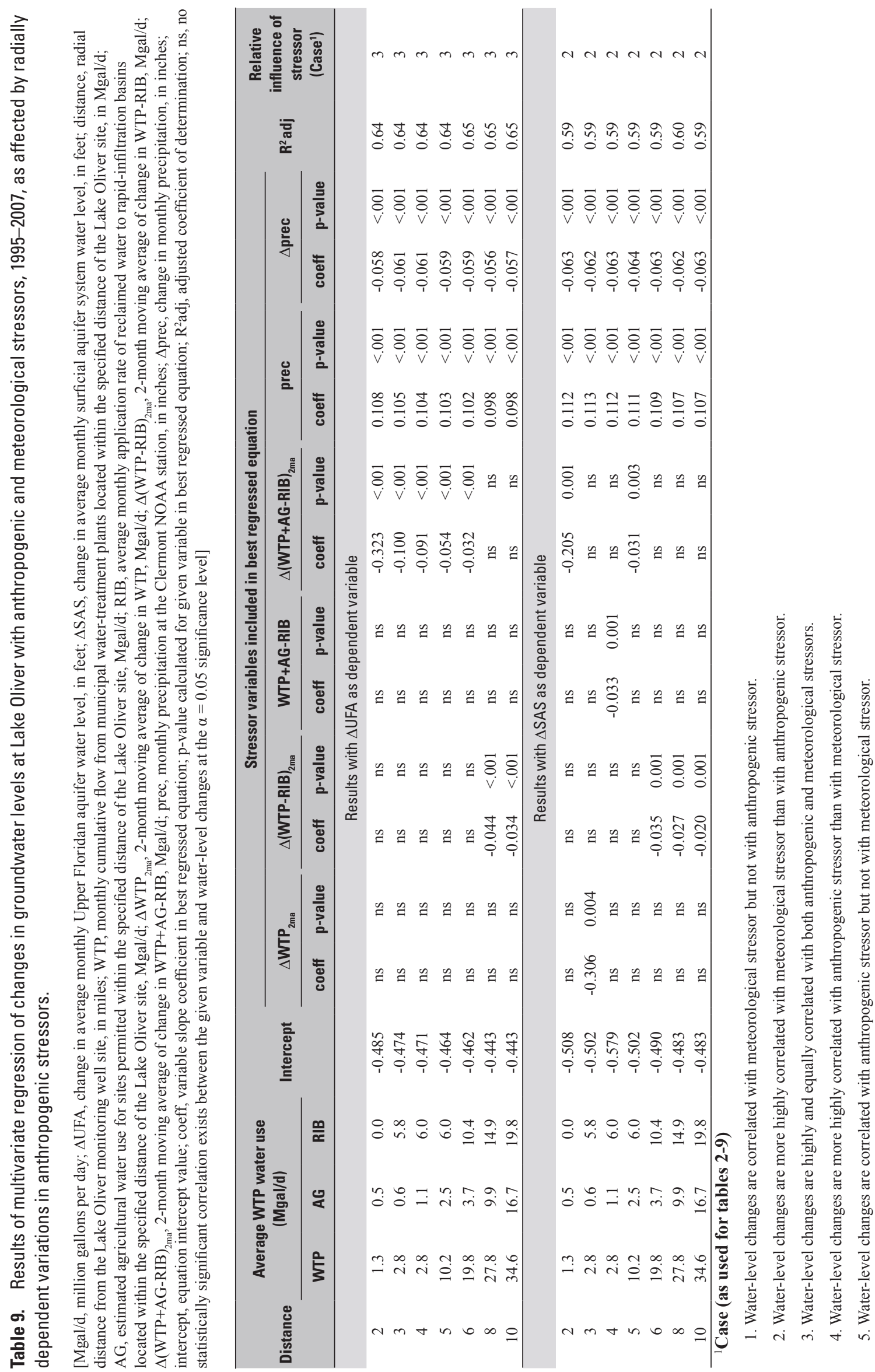
Error also can be introduced by inaccuracies in specified anthropogenic stressor locations. WTP flows and locations, for example, were used in place of well-specific locations and withdrawals. Additionally, the locations of agricultural water-supply wells were assumed to coincide with the centroids of distributed acreages, which may not represent accurate locations.

Finally, other explanatory variables that affect water levels but were not considered here include land-use modifications such as changes in impervious covers, ditching, canals, and other drainage modifications. It also is possible that substantive groundwater withdrawals from Lower Floridan aquifer well fields, which were located within the 10-mi study areas but were not included in the analyses, may have affected water levels at Charlotte Street. Similarly, groundwater withdrawals not accounted for outside of the 10-mi study areas may also have affected water-level changes and contributed to unexplained variance in the regression results.

\section{Summary}

Groundwater withdrawals in east-central Florida have increased steadily during the latter half of the 20th century and concern exists that continued development may adversely affect sensitive water resources. Much of the groundwater used for municipal, agricultural, commercial, and industrial supply is pumped from the Upper Floridan aquifer (UFA), a semiconfined sequence of highly transmissive carbonate rocks. Withdrawals from this system not only lower the potentiometric surface, which may reduce the discharge from UFA springs, but also can lower water levels in the overlying unconfined surficial aquifer system (SAS). Lowered SAS water levels, in turn, can affect other sensitive water resources such as wetlands. In addition to groundwater withdrawals, natural meteorologic stressors such as precipitation and evapotranspiration influence groundwater levels and affect water resources. However, often it is not apparent how the two stressors contribute to changes in SAS and UFA water levels. Consequently, the trends and fluctuations observed in hydrologic data reflect the combined effects of both meteorologic and anthropogenic stressors and thus pose difficulties for water managers tasked with assessing the impacts of new water-use permits in resource-sensitive areas, or of implementing wateruse restrictions during periods of drought.

Regression analyses were used to examine the relations between UFA and SAS groundwater levels and water-level changes with anthropogenic and meteorological stressors at two monitoring well sites (Charlotte Street and Lake Oliver) located in areas of east-central Florida recognized as having sensitive water-resource issues. The Charlotte Street site in Seminole County is situated in a localized wetland environment surrounded by a highly developed urbanized area, while the Lake Oliver site in Orange County is located in a less developed urban environment but one having considerable agricultural land use.

Groundwater withdrawals required to meet municipal demands were quantified within a 10 -mi radius of both sites, while agricultural-related withdrawals and reclaimed-water applications to rapid-infiltration basins (RIBs), which provide recharge to both aquifers, were included as anthropogenic stressors at Lake Oliver. The mean monthly flows from municipal water-treatment plants were used as surrogate quantities for well-specific withdrawal rates. Agricultural withdrawals, which are not metered in east-central Florida, were estimated by the Agricultural Field Scale Irrigation Requirements Simulation (AFSIRS) model and applied to the centroids of receiving crop acreages. Meteorological stressors of interest included precipitation and potential evapotranspiration. Precipitation data were acquired from the nearby Sanford and Clermont National Oceanic and Atmospheric Administration (NOAA) rainfall stations, while PET was estimated from the Priestley-Taylor equation using data collected from a statewide PET monitoring network. Analyses were conducted on a monthly basis over a 13-year period of record (1995-2007) to be consistent with the timeframe being used in concurrent and more regional data-mining and numerical modeling studies.

Simple linear regression was used as a screening tool to identify anthropogenic and meteorological stressors best related with water levels and water-level changes for inclusion in the multivariate analyses; examine the influence of persistence between the response and explanatory variables; and provide comparative results for the multivariate analyses. Results indicated that mean monthly UFA and SAS water levels, and water-level changes, were influenced by both anthropogenic and meteorological stressors, though most relations were poor to fair $\left(\mathrm{R}^{2}<0.50\right)$. Water levels and water-level changes were sensitive to persistence of both stressors, as $\mathrm{R}^{2}$ values could be improved by regressing the response variables with moving averaged values of explanatory variables, which accounted for the influence of conditions in prior months. While water levels were better related to monthly values of anthropogenic and meteorological stressors, changes in water levels were better related to changes in monthly stressor values.

Multivariate analyses produced fits of the data that explained a greater degree of the variance in water levels and water-level changes than did simple linear regression $\left(\mathrm{R}_{\text {adj }}^{2}\right.$ values ranging from 0.40 to 0.89$)$. Consecutive monthly water levels were found to be serially correlated, therefore, only every fourth month was used in these analyses. Accordingly, four groupings of 3 months each were examined. Monthly changes in water levels were not serially correlated, included all 12 months, and provided the better data set for subsequent analyses. While water levels and water-level changes were correlated with the two stressors at both sites, UFA water levels were more highly related to anthropogenic stressors at Lake Oliver but with meteorological stressors at Charlotte Street. SAS water levels were best related with meteorological stressors at both sites. Changes in UFA water levels, however, were equally related with the two stressors at both sites, while changes in SAS levels were equally related with the two stressors at Charlotte Street but were more highly related with meteorological stressors at Lake Oliver. At Lake Oliver, changes in UFA water levels were highly and equally 
influenced by both precipitation and the difference between municipal withdrawals and RIB application rates.

Seasonal variations in groundwater withdrawals, RIB applications, and precipitation affected the relative influences of anthropogenic and meteorological stressors on changes in UFA and SAS groundwater levels at both sites. At Charlotte Street, changes in UFA water levels were more influenced by meteorological stressors during the winter months, when withdrawals were minimized, but were more influenced by withdrawals in the spring months, when this stressor was maximized. At Lake Oliver, changes in UFA water levels were more influenced by groundwater withdrawals for all but the winter season and were related solely with withdrawals in the summer months. While drawdown in UFA levels produced by large increases in withdrawals between the winter and spring seasons (from an average monthly rate of 22.4 to $55.7 \mathrm{Mgal} / \mathrm{d}$ ) likely accounted for the strong association with pumpage in the spring, the exclusive association between water-level changes and summer withdrawals was probably due to recovery of UFA water levels that occurred between the spring and summer seasons as withdrawals were reduced from $55.7 \mathrm{Mgal} / \mathrm{d}$ to $22.8 \mathrm{Mgal} / \mathrm{d}$.

Except for the winter months, when changes in both UFA and SAS water levels were more influenced by meteorological stressors, seasonal changes in UFA levels were more influenced by anthropogenic stressors than were changes in SAS water levels. At Charlotte Street, changes in SAS levels were influenced solely by precipitation and PET during the winter and summer seasons, but were equally influenced by anthropogenic and meteorological stressors in the fall. At Lake Oliver, changes in SAS water levels were better related to meteorological stressors across all seasons.

Water-level changes were sensitive to changes in stressor values that occurred in previous months. Change in the 2-month moving average of municipal groundwater withdrawals was the single anthropogenic stressor most often included in the best regressed models at Charlotte Street, while most of the best models at Lake Oliver included the 2-month moving average of either municipal withdrawals or the difference between municipal withdrawals and RIB applications. Overall, 40 to 87 percent of the variance in UFA and SAS water-level changes could be explained by the explanatory variables. Highest $\mathrm{R}_{\text {adj }}^{2}$ values were obtained for the spring season, when withdrawals were peaked, while lowest values were obtained for the winter or summer seasons.

Monthly water-level changes, which tended to be equally influenced by anthropogenic and meteorological stressors at both sites between 1995 and 2007, were more influenced by one or the other stressor during extended (12 months or greater) periods of hydrologic extreme. During dry periods, changes in UFA water levels at Charlotte Street were more influenced by municipal withdrawals, while changes in SAS water levels were more influenced by meteorological stressors. At Lake Oliver, however, changes in both UFA and SAS water levels were more influenced by meteorological stressors during dry periods. Interestingly, changes in both UFA and SAS water levels were better related with anthropogenic stressors at both sites during similar wet periods of record, from April 1995 to June 1996 at Charlotte Street and from April 1995 to April 1996 at Lake Oliver. The relations here can be attributed, in part, to the recovery of UFA and SAS water that occurred as withdrawals decreased with wetter conditions. Finally, a greater percentage of the variance in water-level changes at both sites could be associated with the two stressors during periods of hydrologic extreme as compared with the more hydrologically averaged conditions represented by the entire 13-year period of record.

Accounting for the regional effects of anthropogenic stressors had limited influence on water-level changes at Charlotte Street and virtually no influence on changes at Lake Oliver. At Charlotte Street, water-level changes were influenced solely by precipitation and PET when accounting for just the $2.2 \mathrm{Mgal} / \mathrm{d}$ of withdrawals located within $2 \mathrm{mi}$ of the site. At a radius of $2.5 \mathrm{mi}$, however, where cumulative withdrawals totaled about $9.5 \mathrm{Mgal} / \mathrm{d}$, water-level changes were equally influenced by both anthropogenic and meteorological stressors. Accounting for municipal groundwater withdrawals beyond a 3-mi radius from Charlotte Street had no appreciable effect on relations between water-level changes and stressors.

At Lake Oliver, and at all distances, UFA levels were influenced equally by anthropogenic and meteorological stressors while SAS levels were more closely associated with meteorological stressors. The most influential anthropogenic stressors included some combination of municipal withdrawals, agricultural withdrawals, and RIB application. The most influential meteorological stressors were precipitation and change in precipitation.

\section{References Cited}

Conover, W.L., 1999, Practical nonparametric statistics (3d ed.): New York, John Wiley, 584 p.

Durbin, J., and Watson, G.S., 1951, Testing for serial correlation in least squares regression II: Biometrika, v. 38.

Helsel, D.R., and Hirsch, R.M., 2002, Statistical methods in water resources: U.S. Geological Survey, Techniques of Water-Resources Investigations book 4, chap. A3, 510 p.

Knowles, L., Jr., O’Reilly, A.M., and Adamski, J.C., 2002, Hydrogeology and simulated effects of ground-water withdrawals from the Floridan aquifer system in Lake County and in the Ocala National Forest and vicinity, north-central Florida: U.S. Geological Survey Water-Resources Investigations Report 02-4207, 139 p.

Marella, R.L., 2004, Water withdrawals, use, discharge, and trends in Florida, 2000: U.S. Geological Survey Scientific Investigations Report 2004-5151, 136 p. 
Murray, L.C., Jr., 2007, Analyses of water-level differentials and variations in recharge between the surficial and Upper Floridan aquifers in east-central and northeast Florida: U.S. Geological Survey Scientific Investigations Report 2007$5081,58 \mathrm{p}$.

Murray, L.C., Jr., 2009, Relations between municipal water use and selected meteorological parameters and drought indices, east-central Florida and northeast Florida: U.S. Geological Survey Scientific Investigations Report 2009-5010, $31 \mathrm{p}$.

Murray, L.C., Jr., and Halford, K.J., 1996, Hydrogeologic conditions and simulation of ground-water flow in the greater Orlando area, east-central Florida: U.S. Geological Survey Water-Resources Investigations Report 96-4181, $100 \mathrm{p}$.

Priestley, C.H.B., and Taylor, R.J., 1972, On the assessment of surface heat flux and evaporation using large-scale parameters: Monthly Weather Review 100, p. 81-92.

Sepulveda, N.S., 2002, Simulation of ground-water flow in the intermediate and Floridan aquifer systems in peninsular Florida: U.S. Geological Survey Water-Resources Investigations Report 02-4009, 130 p.

Smajstrla, A.G., 2008, Technical Manual—Agricultural field scale irrigation requirements simulation model, version 5.5: St. Johns River Water Management District Special Publication SJ2008-SP17, 6 p.

Tibbals, C.H., 1990, Hydrology of the Floridan aquifer system in east-central Florida: U.S. Geological Survey Professional Paper 1403-E, 98 p.

U.S. Geological Survey, 2009, Florida Water Science Center Hydrologic Data Portal (http://hdwp.er.usgs.gov).

Watts, K.R., 1995, Regression models of monthly water-level change in and near the closed basin division of the San Luis Valley, south-central Colorado: U.S. Geological Survey Water-Resources Investigations Report 96-4181, 100 p. 
Appendix 1 
Table 1-1. Water-treatment plants located within 10 miles of the Charlotte Street monitoring well site.

[Map number refers to figure 4; WTP, water-treatment plant; RIB, rapid-infiltration basin; RCID, Reedy Creek Improvment District; OCU, Orange County Utilities; SE, southeast; SW, southwest; NE, northeast; NW, northwest; Inc. Incorporated; no., number]

\begin{tabular}{|c|c|c|}
\hline $\begin{array}{c}\text { Map } \\
\text { number }\end{array}$ & Utility/Owner & $\begin{array}{c}\text { Plant/site } \\
\text { name }\end{array}$ \\
\hline 1 & City of Longwood & no. 1 \\
\hline 2 & Sanlando Utilities & Knollwood \\
\hline 3 & City of Longwood & no. 2 \\
\hline 4 & Sanlando Utilities & Despinar \\
\hline 5 & Apple Valley & \\
\hline 6 & City of Casselberry & no. 2 \\
\hline 7 & City of Altamonte Springs & Spring Lake \\
\hline 8 & Cit of Casselberry & Howell Park \\
\hline 9 & Seminole County Utilities & SE - Indian Hills \\
\hline 10 & Bretton & Druid Hills \\
\hline 11 & City of Winter Springs & Bahama St. \\
\hline 12 & City of Maitland & Thistle \\
\hline 13 & City of Winter Springs & Shenendoah \\
\hline 14 & Weathersfield & \\
\hline 15 & Meredith Manor & \\
\hline 16 & City of Altamonte Springs & Pearl Lake \\
\hline 17 & Seminole County Utilities & NE - CC Heights \\
\hline 18 & Seminole County Utilities & NE - Greenwood \\
\hline 19 & Sanlando Utilities & Wekiva Hunt \\
\hline 20 & City of Altamonte Springs & Pearl Lake \\
\hline 21 & City of Eatonville & \\
\hline 22 & City of Casselberry & South \\
\hline 23 & Seminole County Utilities & SE - Consumers \\
\hline 24 & Seminole County Utilities & SW - Lynwood \\
\hline 25 & City of Lake Mary & \\
\hline 26 & Seminole County Utilities & NW - Heathrow \\
\hline 27 & City of Winter Springs & Tuskawilla \\
\hline 28 & Seminole County Utilities & NW - Hanover \\
\hline 29 & City of Sanford & Auxillary \\
\hline 30 & City of Sanford & Main \\
\hline 31 & Seminole County Utilities & NW - Markham \\
\hline 32 & City of Oviedo & Mitchell Hammock \\
\hline 33 & City of Oviedo & Main \\
\hline 34 & Seminole County Utilites & NW - Lake Monroe \\
\hline 35 & City of Apopka & Grossenbacher \\
\hline 36 & Seminole County Utilites & SE - Lake Hayes \\
\hline 37 & City of Oviedo & A.M. Jones \\
\hline
\end{tabular}


Table 1-2. Water-treatment plants and rapid-infiltration basins located within 10 miles of the Lake Oliver monitoring well site.

[Map number refers to figure 4; WTP, water-treatment plant; RIB, rapid-infiltration basin; RCID, Reedy Creek Improvment District; OCU, Orange County Utilities; SE, southeast; SW, southwest; NE, northeast; NW, northwest; Inc. Incorporated; no., number]

\begin{tabular}{|c|c|c|c|}
\hline $\begin{array}{c}\text { Map } \\
\text { number }\end{array}$ & $\begin{array}{c}\text { Facility } \\
\text { type }\end{array}$ & Utility/Owner & $\begin{array}{c}\text { Plant/site } \\
\text { name }\end{array}$ \\
\hline 1 & WTP & Lake Utilities Services & Greater Groves \\
\hline 2 & WTP & Lake Utilites Services & Lake Louisa \\
\hline 3 & WTP & Southlake Utilities & \\
\hline 4 & WTP & RCID & A \\
\hline 5 & WTP & RCID & B \\
\hline 6 & WTP & RCID & $\mathrm{C}$ \\
\hline 7 & WTP & RCID & $\mathrm{D}$ \\
\hline 8 & WTP & Orange County Utilities & Vistana \\
\hline 9 & WTP & Toho Water Authority & Indian Ridge \\
\hline 10 & WTP & Toho Water Authority & Southwest \\
\hline 11 & WTP & Toho Water Authority & Northwest \\
\hline 12 & WTP & Toho Water Authority & Camelot West \\
\hline 13 & WTP & Orange County Utilities & Cypress Walk \\
\hline 14 & WTP & Polk County Utilities & NE - Edgehill \\
\hline 15 & WTP & Polk County Utilities & NE - Regal Inn \\
\hline 16 & WTP & Polk County Utilities & NE - Van Fleet \\
\hline 17 & WTP & Polk County Utilities & NE - Davenport \\
\hline 18 & WTP & Polk County Utilities & NE - Berry \\
\hline 19 & WTP & Polk County Utilities & NE - Holiday Inn \\
\hline 1 & RIB & RCID & all RIB sites \\
\hline 2 & RIB & OCU ConservII & no. 2 \\
\hline 3 & RIB & OCU ConservII & no. 3 \\
\hline 4 & RIB & OCU ConservII & no. 4 \\
\hline 5 & RIB & OCU ConservII & no. 5 \\
\hline 6 & RIB & OCU ConservII & no. 6 \\
\hline 7 & RIB & OCU ConservII & no. 7 \\
\hline 8 & RIB & OCU ConservII & no. 8 \\
\hline 9 & RIB & OCU ConservII & no. 9 \\
\hline 10 & RIB & Utilities Inc. & Lake Groves \\
\hline 11 & RIB & Southlake Utilities & Southlake \\
\hline
\end{tabular}




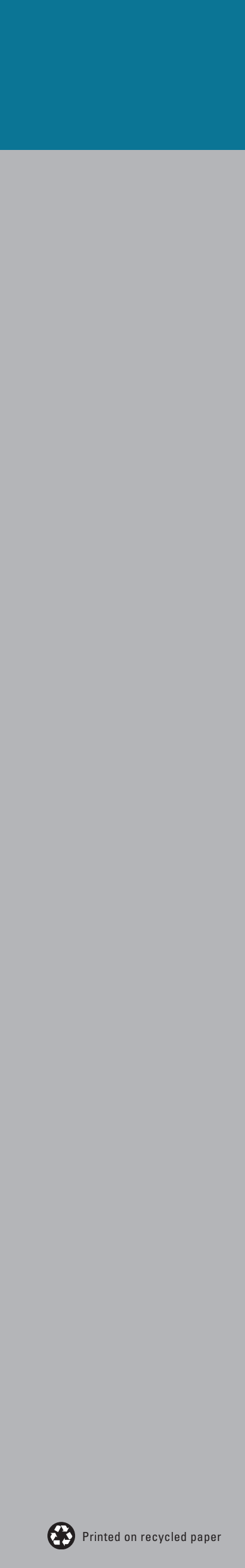

